\title{
Restoration and Conservation of Priority Areas of Caatinga's Semi-Arid Forest Remnants Can Support Connectivity within an Agricultural Landscape
}

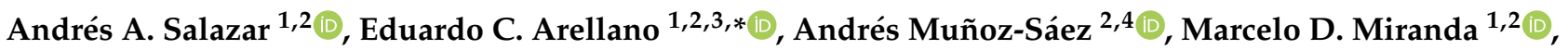 \\ Fabiana Oliveira da Silva ${ }^{5,6}{ }^{(D}$, Natalia B. Zielonka ${ }^{7}(\mathbb{D})$, Liam P. Crowther ${ }^{7}\left(\mathbb{D}\right.$, Vinina Silva-Ferreira ${ }^{8}(\mathbb{D})$, \\ Patricia Oliveira-Reboucas ${ }^{9}$ a and Lynn V. Dicks ${ }^{7,10} \mathbb{C}$
}

check for

updates

Citation: Salazar, A.A.; Arellano, E.C.; Muñoz-Sáez, A.; Miranda, M.D.; Oliveira da Silva, F.; Zielonka, N.B.; Crowther, L.P.; Silva-Ferreira, V.; Oliveira-Reboucas, P.; Dicks, L.V Restoration and Conservation of Priority Areas of Caatinga's Semi-Arid Forest Remnants Can Support Connectivity within an Agricultural Landscape. Land 2021, 10, 550. https://doi.org/10.3390/ land10060550

Academic Editors: Diane L. Haase, Jeremiah R. Pinto and Owen T. Burney

Received: 5 April 2021

Accepted: 18 May 2021

Published: 21 May 2021

Publisher's Note: MDPI stays neutral with regard to jurisdictional claims in published maps and institutional affiliations.

Copyright: (c) 2021 by the authors. Licensee MDPI, Basel, Switzerland. This article is an open access article distributed under the terms and conditions of the Creative Commons Attribution (CC BY) license (https:/ / creativecommons.org/licenses/by/ $4.0 /)$.
1 Facultad de Agronomía e Ingeniería Forestal, Pontificia Universidad Católica de Chile, Santiago 7830436, Chile; ajsalazar@uc.cl (A.A.S.); mmirands@uc.cl (M.D.M.)

2 Center of Applied Ecology and Sustainability (CAPES), Santiago 7820244, Chile; andrmunoz@uchile.cl

3 Centro Interdisciplinario de Cambio Global, Pontificia Universidad Católica de Chile, Santiago 7820436, Chile

4 Facultad de Ciencias Agronómicas, Universidad de Chile, Santiago 8820808, Chile

5 Departamento de Educação em Ciências Agrarias e da Terra, Universidade Federal de Sergipe, Campus do Sertão (UFS), Nossa Senhora da Glória 49680-000, Brazil; fabianaosilva@academico.ufs.br

6 National Institute of Science and Technology in Interdisciplinary and Transdisciplinary Studies in Ecology and Evolution (INCT-IN-TREE), Salvador 40110-906, Brazil

7 School of Biological Sciences, University of East Anglia, Norwich NR4 7TJ, UK; n.zielonka@uea.ac.uk (N.B.Z.); L.Crowther@uea.ac.uk (L.P.C.); Lvd22@cam.ac.uk (L.V.D.)

8 Colegiado de Ciências Biológicas, Universidade Federal do Vale do São Francisco, Petrolina 56300-990, Brazil; vinina.ferreira@univasf.edu.br

9 Departamento de Tecnologia e Ciências Sociais, Universidade do Estado da Bahia-Campus III (UNEB), Juazeiro 48904-711, Brazil; preboucas@uneb.br

10 Department of Zoology, University of Cambridge, Cambridge CB2 3EJ, UK

* Correspondence: eduardoarellano@uc.cl

Abstract: Land-use and land-cover (LULC) changes are major drivers of biodiversity loss in semi-arid regions, such as the Caatinga biome located in the Northeast of Brazil. We investigated landscape dynamics and fragmentation in an area of the São Francisco Valley in the Brazilian Caatinga biome and measured the effect of these dynamics on ecological, functional and structural connectivity over a 33-year period (1985-2018). We calculated landscape connectivity indices based on graph theory to quantify the effect of further agricultural expansion on ecological connectivity at the landscape scale. We used a multicriteria decision analysis that integrates graph-based connectivity indices at the habitat patch scale, combined with an index of human disturbance to identify patches that, if conserved and restored, preserve the connectivity of the landscape most effectively. In the period studied, agriculture increased at a rate of $2104 \mathrm{ha}$ /year, while native Caatinga vegetation decreased at a rate of 5203 ha/year. Both dense and open Caatinga became more fragmented, with the number of fragments increasing by $85.2 \%$ and $28.6 \%$, respectively, whilst the average fragment size decreased by $84.8 \%$ and $6.1 \%$ for dense and open Caatinga, respectively. If agriculture patches were to expand by a $300 \mathrm{~m}$ buffer around each patch, the overall ecological connectivity could be reduced by $6-15 \%$, depending on the species' (small- to mid-size terrestrial vertebrates) mobility characteristics for which the connectivity indices were calculated. We provided explicit spatial connectivity and fragmentation information for the conservation and restoration of the Caatinga vegetation in the studied area. This information helps with conservation planning in this rapidly changing ecosystem.

Keywords: land-use and land-cover change; landscape connectivity; agriculture; conservation planning; landscape restoration; Caatinga biome 


\section{Introduction}

Land-use and land-cover (LULC) change is one of the main agents of terrestrial ecosystem transformation $[1,2]$, due to its impacts on soil and water quality, biodiversity and global climate [3,4]. These changes particularly relate to an increased human population and the expansion of intensive agriculture $[5,6]$. From a landscape ecology perspective, LULC change in natural systems leads to habitat reduction, vegetation fragmentation and a decrease in ecological connectivity, which have negative consequences for biodiversity [7-9].

Connectivity is defined by the movement capacity of organisms (and their genes) in a landscape and it is conditioned by the landscape structure and composition [10]. Connectivity is considered crucial for biodiversity conservation and for mitigating the negative effects of habitat fragmentation [11,12]. Increasing connectivity between remnants of natural vegetation enhances species conservation at the metapopulation level [13-15], which can improve the effectiveness of protected areas by providing corridors and stepping stones that interconnect biodiversity across landscapes and increase the quality of the productive matrix [16-18]. The graph theory helps to assess the state or degree of connection between vegetation fragments in a given region by depicting the landscape as a spatial network model [15]. In this model, nodes are represented by habitat fragments that are connected by links, allowing species to disperse between fragments $[19,20]$. In agroforestry landscapes with productive areas, the results of this model can be used for decision making and planning of conservation and restoration areas [21,22].

The Caatinga biome is one of the most diverse dryland ecosystems [23] and consists of tropical and subtropical dry, broadleaf forests, covering most of the Brazilian Northeast [24]. It covers an area of about $844,453 \mathrm{~km}^{2}$, equivalent to $10 \%$ of the Brazilian territory [25]. The Caatinga is threatened by increasing land-use intensity $[23,26]$. Only $1.75 \%$ of the original Caatinga area is protected by Integral Protection Conservation Units, and 7\% by Sustainable Use Conservation Units [7].

The Caatinga has a long history of land-use changes. Historically, its mosaic structure of dense forest, shrubland and open areas were covered mostly by herbaceous vegetation that was maintained by megaherbivores [27,28]. In the early 1500s, Europeans settled in Caatinga and introduced cattle and goats [29] whilst introducing European diseases [30]. This led to the loss of nearly half of Caatinga's original vegetation cover to desertification, agricultural expansion, overgrazing of open areas, fuelwood extraction and hunting around European settlements, whilst the decline in megaherbivores may have further contributed to the homogenization of Caatinga and the reduction in naturally open areas [26,31-33]. Despite Caatinga being considered a mosaic of open areas and dense woodlands, it is documented that the recent anthropogenic exploitation, introduction of exotic species, and climate change have been driving the general degradation of Caatinga [26,34,35]. For example, despite the traditional land-use type being animal grazing, recent practices associated with this are more damaging, as vegetation is intentionally opened up to stimulate the growth of introduced herbaceous vegetation to ensure feed for grazing livestock [34]. Caatinga is also converted to agriculture or cut down for timber, which prevents natural forest regeneration [33]. A recent study showed that agriculture, particularly in the form of highly profitable and large farms, is one of the main drivers of land-use change in some areas of the Caatinga [36].

In many areas of the Caatinga, human impacts are higher in more productive areas with more humid and fertile soils [34]. The cities of Petrolina and Juazeiro within the Caatinga semi-arid region of northeastern Brazil lie at the center of an important agricultural region that has experienced major growth due to the development of irrigated agriculture for fruit exportation [37]. The construction of a dam on the São Francisco River in the early 1980s spurred land-use change, leading to multiple irrigation and agricultural development programs in the region [32,38]. In the São Francisco Valley, fruit growing is the main driving force behind economic growth in the region [39]. In this area, the 
Caatinga vegetation is under a lot of land-use pressure, and present high levels of chronic, human-caused disturbance [35].

The development of sustainable agriculture policies requires the increase in the understanding of the ecological impacts on biodiversity at the landscape level of farming systems [40]. In the Caatinga biome, conservation programs around agriculture land need to urgently stop species and natural ecosystem loss [34]. To fully understand the impact of agricultural development on Caatinga biodiversity and provide a quantification of recent changes and the current landscape situation, the aim of this paper is to analyze the changes in composition, configuration, and connectivity of the São Francisco Valley landscape over time. We anticipate that intensive agriculture is the main driver of land-use change within this region [33], and increases progressively over time, leading to reduced native vegetation cover (decreasing structural connectivity), greater fragmentation and a decline in ecological connectivity (increased barriers for terrestrial animal movement). In this paper, we combined Landsat images with a set of high-resolution land cover maps from the MapBiomas project collection 4.1 [41], supported by ground-truthing from field surveys, to address the following questions:

(1) How have the cover and spatial configuration of Caatinga and agricultural habitat changed over the period of 1985-2018 in the São Francisco Valley landscape?

(2) How would different patterns of future hypothetical continuing of agricultural expansion influence the connectivity of the landscape from the perspective of species with different levels of dispersal mobility?

(3) If conserved or restored, which native vegetation areas preserve the connectivity of the landscape most effectively under agricultural expansion?

\section{Materials and Methods}

\subsection{Study Area}

The study area is located in the Brazilian Caatinga biome, in the northeast of the country. Within the Caatinga, we selected an area covering 846,400 ha that lies between the following geographic coordinates: $8^{\circ} 58^{\prime} 4^{\prime \prime}$ and $9^{\circ} 39^{\prime} 7^{\prime \prime} \mathrm{S}$; and $40^{\circ} 00^{\prime} 2^{\prime \prime}$ and $41^{\circ} 10^{\prime} 3^{\prime \prime} \mathrm{W}$. This area is located at the sub middle section of the São Francisco River basin, between the federal states of Bahia (BA) and Pernambuco (PE) (Figure 1). The study area includes part of the São Francisco River, urban areas of the cities of Casa Nova, Sobradinho, Petrolina, Juazeiro and Lagoa Grande, pastures, native vegetation and irrigated agriculture [42].

The native vegetation is a mosaic of arboreal or shrub forests, comprising mainly trees and low shrubs, many of which have thorns, microphylla, and some xerophytic features, as well as open areas $[27,29,43]$. The Caatinga's natural vegetation is characterized by leaf shedding in the dry season (August-November) [44] and is categorized as a dry tropical forest, formed by two types: a dense hyperxerophyllous forest and an open forest in different stages of development, featuring poaceae and open areas [44]. Caatinga can be broadly classified into two types and we followed the classification that has previously been used [41,42], which divided Caatinga into (1) the dense hyperxerophyllous forest, which has a woody cover of approximately $60-80 \%$ (dense Caatinga); and (2) the open forest, which is characterized by being in different stages of development, featuring grasses and abandoned areas, and has a woody cover of approximately $20-60 \%$. Natural open areas are common around rock formations and in the areas too dry to sustain trees [32]. More recently, open areas that are characterized by low vegetation cover, density, and basal area, have been linked to historical clear-cuts for timber and high grazing pressures by livestock [34]; these can be characteristic of Caatinga degradation and are common in our study region [33,34]. In this area, the maximum temperature ranges from $29.7^{\circ} \mathrm{C}$ (July) to $34.2^{\circ} \mathrm{C}$ (November), with an annual mean of $32.3^{\circ} \mathrm{C}$; the minimum temperature ranges from $20.0{ }^{\circ} \mathrm{C}$ (July) to $23.5{ }^{\circ} \mathrm{C}$ (December) with an annual mean of $22.2^{\circ} \mathrm{C}$ [32]. Mean monthly rainfall ranges from $1.4 \mathrm{~mm}$ (August) to $114.1 \mathrm{~mm}$ (March); most of it (70.4\%) falls between January and April, with an annual mean of $482.6 \mathrm{~mm}$ [32]. 


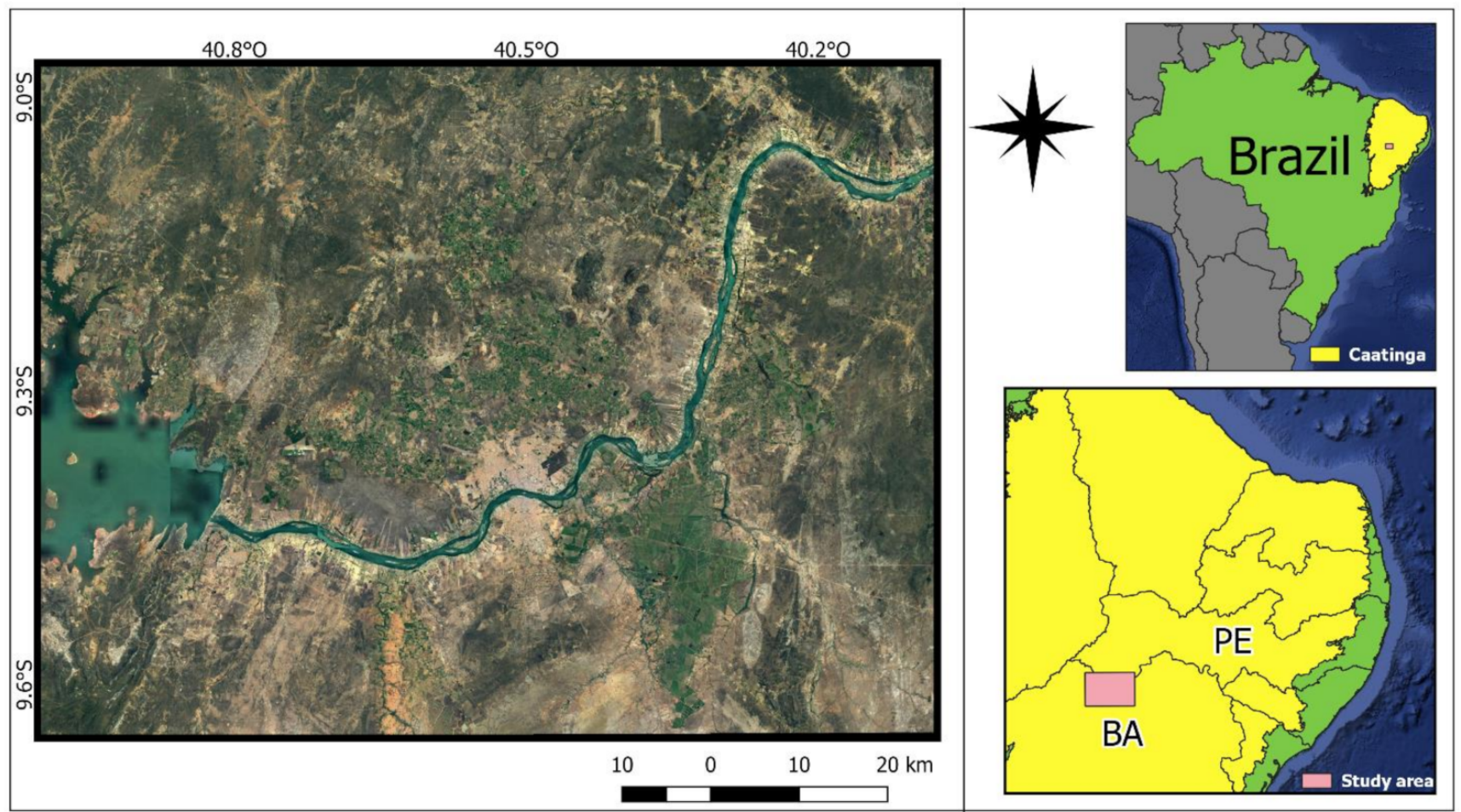

Figure 1. Study area within the Caatinga biome, in Northeast Brazil (BA: Bahia state, PE: Pernambuco state). The pink rectangle represents the whole study area.

\subsection{Processing and Classification of Satellite Images}

A 33-year spatiotemporal analysis $(1985,2000$ and 2018) was conducted to analyze temporal changes in the landscape structure. Working on the Google Earth Engine (GEE) platform and Landsat images (sensors TM, ETM+ and OLI), we used the "best available pixel" method [45] to generate image composites with clear skies and the greatest possible absence of clouds [46] that were representative of the dry season, between August and November [47]. Surface reflectance products were subjected to topographic, radiometric, and atmospheric corrections $[48,49]$.

To classify the Landsat images, we performed field surveys in 2019 to collect control points distributed in the agroecosystems and the native vegetation within the study area. These control points were complemented with LULC data obtained by photointerpretation of high-resolution images available from GEE and LULC maps from MapBiomas project collection 4.1 [41]. These maps cover the entire territory of Brazil at a spatial resolution of $30 \mathrm{~m}$, from 1985 to 2018, with more than 80\% accuracy [41]. MapBiomas LULC maps are classified into 19 classes and the native vegetation of the study area is classified as savanna [41]. A random forest (RF) supervised learning algorithm [50] was applied to classify the images in different LULC classes, obtaining one image for each year considered $[47,51,52]$. We classified the native vegetation into two classes (open and dense Caatinga) according to their structure.

Based on previous studies in the Caatinga biome, we defined the following LULC classes: (1) water, (2) urban, (3) pasture, (4) agriculture (irrigated croplands), (5) open Caatinga (open native forest), and (6) dense Caatinga (dense native forest) $[32,44,53]$. We used a minimum mapping unit greater than 5 pixels [54], and the classification accuracy and the kappa index were evaluated through a confusion matrix between the reference data and the classified data [55].

\subsection{Landscape Composition and Configuration Analysis}

The resulting LULC maps were used to estimate changes in the spatial patterns during the study period (1985-2018). The quantification and comparison of the spatial 
layout of native vegetation fragments were carried out based on the following set of landscape metrics, which were chosen after reviewing native vegetation fragmentation studies [15,54,56]: (1) number of patches; (2) mean patch area (ha); (3) largest patch index (landscape percentage covered by the largest patch); and (4) the mean Euclidean nearest neighbor distance (m). These metrics were quantified in $\mathrm{R}$ version 4.0.4 [57], using the "landscape metrics" package [58].

\subsection{Determining the Distance Threshold for Landscape Connectivity Analysis}

To determine graph-based connectivity indices, it is necessary to choose or calculate a threshold of dispersal distances of the different species of interest $[19,59,60]$. We calculated two graph-based landscape connectivity indices-the "Integral Index of Connectivity" (IIC) and the "Class Coincidence Probability" (CCP)—that allowed us to define distance thresholds between fragments [20]. The IIC integrates into a single value of connectivity, the area of fragments of native vegetation (hereafter habitat patches), and the connectivity of the landscape [61]. The habitat patches of the focal species are represented as nodes, and the topological relations or connections between them are represented as links based on graph theory [62]. The values of IIC range from 0 to 1 , increasing as the connectivity improves, thus a value of 1 would be reached in the hypothetical case of a landscape being totally occupied by the habitat. The IIC is calculated as follows [20]:

$$
I I C=\frac{\sum_{i=1}^{n} \sum_{j=1}^{n} \frac{a_{i} a_{j}}{1+n l_{i j}}}{A_{L}^{2}}
$$

where $a(i$ or $j)$ is the area of each patch; $n l_{i j}$ is the number of links in the shortest path (topological distance) between patches $i$ and $j$. For patches that are not connected (belong to different components), the numerator in the sum of the equation equals zero $\left(n l_{i j}=\infty\right)$. When $i=j$ then $n l_{i j}=0$ (no links needed to reach a certain patch from itself). $n$ is the total number of patches in the landscape; $A_{L}$ is the total area of the landscape.

$C C P$ is defined as the probability that two randomly selected points in a habitat belong to the same network [20]. CCP is calculated as follows:

$$
C C P=\sum_{i=1}^{N C}\left(\frac{c_{i}}{A_{c}}\right)^{2}
$$

where $N C$ is the total number of components in the landscape, where a component (connected region) is a set of nodes for which a path exists between every pair of nodes (an isolated patch makes up a component itself); $c_{i}$ is the total area of each component (i.e., the sum of the areas of the patches belonging to that component); and $A_{C}$ is the total area of patches in the landscape. $C C P$ values range from 0 to 1 . Higher values indicate higher connectivity.

To calculate the distance thresholds upon which to base the connectivity indices for the landscapes, IIC and CCP indices were calculated at $10 \mathrm{~m}$ intervals for distances between 10 and $1500 \mathrm{~m}$. This was done for the dense Caatinga class because they provide better soil protection and have a greater ecological role than open Caatinga [63], and because these patches better represent the original native vegetation within the studied region, where open Caatinga is often degraded as a result of agricultural expansion, clear-cuts and overgrazing $[33,34]$. Based on these preliminary results that are in agreement with some species of mid-sized animals found in the area, the connectivity distances used to analyze the dense Caatinga were set at 100, 560, 1140 and 20,000 m (see Section 3.3). These (100-1140 m) cover a wide range of different species' responses to landscape patterning [64-66], including the following: Tropidurus hispidus, which is a reptile that can travel distances between patches nearly $100 \mathrm{~m}$ apart [67]; Hydrochoerus hydrochaeris, which is a mammal that has

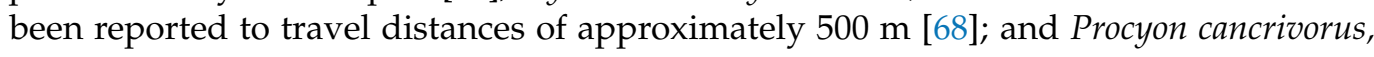
which is a mammal that can travel distances around $1900 \mathrm{~m}$ [69]. The 20,000 $\mathrm{m}$ distance 
was chosen to assess the landscape perception by Herpailurus yagouaroundi, a feline that travels long distances and is one of the most dispersive terrestrial animals found in the study area [70], inhabiting several areas of the Caatinga biome [71,72]; it has been reported in the fragmented forest in the state of São Paulo [64]. All these indices were calculated with the Graphab software version 2.4 [73].

\subsection{Assessment of Hypothetical Agriculture Area Growth Projections}

In order to assess the effect of the conversion of natural habitat into agriculture (irrigated croplands) on the functional connectivity to target taxa (fauna) in the study range, we established three hypothetical projections of agriculture class expansion based on LULC map classification. We created three new LULC maps in which patches of the 'agriculture' land class existing in 2018 were expanded by a buffer of new agricultural land, 100, 200 or $300 \mathrm{~m}$ in width. The first projection, in which all agricultural patches increased by a buffer of $100 \mathrm{~m}$, is equivalent to an agricultural expansion of 5673 ha (6.2\% more agricultural land than in 2018); in the second projection, agriculture expanded by a buffer of $200 \mathrm{~m}$ equivalent to 10,061 ha $(+10.9 \%)$; in the third projection, agriculture expanded by a buffer of $300 \mathrm{~m}$, equivalent to $13,352 \mathrm{ha}(+14.5 \%)$. These projections are consistent with the observed increases in agriculture within the study area between 1985 and 2018 (see Table A5, Appendix B). We used the "Equivalent Connected Area index" $(E C A)$ metric $[14,74]$ to measure the landscape connectivity of the three projections, with and without increases in agricultural land. ECA is the size (area) of a single patch that can provide the same amount of connectivity as observed in the landscape of interest [74]. The formula is as follows:

$$
E C A=\sqrt{\sum_{i=1}^{n} \sum_{j=1}^{n} a_{i} a_{j} P_{i j}}
$$

For a landscape with $n$ habitat patches, $a$ is the area extension of a habitat patch. When $i \neq j, a_{i}$ is patch area $i$ and $a_{j}$ is patch area $j$. $P$ is the probability of connectivity between the two patches. $P_{i j}=1$ when the two patches are connected with a link (i.e., they are closer together than the predefined distance thresholds), and $P=0$ if otherwise. When $i=j, i$ and $j$ are the same patch, so $P_{i j}=1$. Therefore, ECA takes into account the connected area that exists within a habitat patch. ECA generally increases if (1) the size of a habitat patch increases, (2) a new habitat patch is created, or (3) a new forest corridor is created between habitat patches that were previously isolated [74].

ECA was used to determine to what extent only dense Caatinga patches contribute to overall landscape connectivity. When there is a change in the landscape from 2018, such as an increase or decrease in habitat patches-which most likely also implies a variation in the spatial layout of the habitat within the landscape-we can calculate the relative change in the amount of attainable habitat. This is determined by $d E C A=($ finalECA - initialECA)/initialECA [74].

To analyze the impact of the loss of dense Caatinga patches near agricultural land, we calculated a $d E C A$ series comparing the landscape with no increase in the agricultural area (initialECA) to landscapes of the three agriculture expansion projections (finalECA). $d E C A$ was calculated for the four established distances described in $2.4(100,560,1140$ and $20,000 \mathrm{~m})$. These indices were calculated with the Graphab software version 2.4 [73].

\subsection{Prioritization of Caatinga Patches to Conserve and Restore}

Dense Caatinga patches have a higher conservation priority than open Caatinga patches within our study area, characterized by rapid expansion and intensification of agriculture, as they provide higher ecosystem services and protection against anthropogenic disturbance and aridity for functional diversity [75]. In fact, a recent study from Brazil found the loss of forests across agricultural landscapes to have a negative effect on agricultural productivity by reducing crop pollination [76]. As a result, within our study region, conservation priority was given to dense Caatinga patches, while open Caatinga patches 
were prioritized for restoration, as they have a reduced capacity for natural regeneration and contain grasses and abandoned areas [44]. This analysis considered the existing patches based on the 2018 land-cover map.

The importance of each patch in terms of its individual contribution to the maintenance of overall connectivity was measured, using the "Delta IIC" index (dIIC), which is usually represented by the removal of individual patches from the landscape and the quantification of the corresponding decrease in connectivity $[59,77]$. dIIC is calculated as follows:

$$
d I I C_{i}=100 \times \frac{I I C-I I C_{\text {remove }}}{I I C}
$$

Several studies have highlighted the importance of patches with high network centrality in maintaining and enhancing connectivity $[19,59,60]$. We used the Betweenness Centrality $(B C)$ index, which assigns a value to each patch and suggests that high-scoring patches constitute the "backbone of the landscape," as a disproportionately high number of the shortest paths in the entire landscape pass through these patches [77]. $B C$ is calculated as follows [59]:

$$
B C=\sum_{i=1}^{n} \sum_{j=1, i \neq j}^{n} p(i, k, j) / p(i, j)(i \neq j \neq k)
$$

$B C$ quantifies the quantity of a patch and stands in between other patches in a network. It calculates the sum of all shortest paths between all pairs that go through the patch $k$ divided by the sum of all the shortest paths between all pairs of patches. These indices were calculated with the Graphab software version 2.4 [73].

To determine the patches of dense Caatinga that should be conserved, the $\mathrm{dIIC}$ and $B C$ indices were calculated with the dispersal distance of $H$. yagouaroundi $(20 \mathrm{~km}$; [70]), which was captured with camera traps in the study area (unpublished data). Then, the index values were normalized between 0 and 1 to facilitate their integration, where 0 is the lowest possible score and 1 is the highest possible one.

Vegetation patch conservation studies based on functional connectivity should include the intensity of human disturbance [21]. As a supplement to the aforementioned indices, we included the "Chronic Anthropogenic Disturbance Index" (CDI) [35]. This index measures the intensity of human disturbance and depends on several man-made environmental vectors, such as human population, infrastructure, grazing, timber extraction and wildfires; here, we consider the recent increases in overgrazing by livestock and the associated clear-cutting to promote herbaceous growth, extensive timber extraction and increased fire risk associated with human activities (see Introduction section). CDI values range from 0 to 1 , where 0 is the least disturbed pixel and 1 is the most disturbed pixel [35]. The CDI is in raster format with a spatial resolution of $90 \mathrm{~m}$ and may be freely downloaded (https: / /bit.ly /2XEd7v1, accessed on 20 April 2021). In our analysis, higher CDI scores indicate a higher priority for conservation/restoration.

We used dIIC, BC and CDI indices simultaneously to select conservation priority patches. To this end, we conducted a multi-criteria decision analysis (MCDA), which provides a systematic methodology for combining the values of these indices in order to define conservation priorities [78]. To evaluate the different results that we might obtain if we favored connectivity or the magnitude of human disturbance, we created two scenarios with different weights for each index and calculated the weighted linear sum of the indices in each scenario [78]. In the first scenario, the weights were $0.6,0.2$ and 0.2 for CDI, dIIC and $B C$, respectively, and in the second scenario, the weights were $0.2,0.4$ and 0.4 for $\mathrm{CDI}$, dIIC and $B C$, respectively. In this sense, the first scenario considers species sensitive to human disturbances (more weight to CDI) and the second scenario considers species tolerant to the human matrix (less weight to CDI). The prioritization of open Caatinga patches for restoration followed the same methodology. Higher MCDA scores indicate a higher priority for conservation/restoration. 


\section{Results}

\subsection{Spatial-Temporal Change in Land Use and Land Cover}

Over the entire study period (1985-2018), agricultural land increased by $8.2 \%$, at a rate of $2104 \mathrm{ha}$ /year, and open and dense Caatinga forests, combined, decreased by $20.2 \%$, at a rate of -5203 ha/year. The net change in area (ha) seen between 1985 and 2018 can be found in Appendix B (Table A4). Image classification had an overall accuracy of 87\%, 88\% and $90 \%$ for the years 1985, 2000 and 2018, respectively. The Kappa coefficient was 0.85, 0.86 and 0.88 for each year, respectively, indicating high accuracy according to this statistical index [79]. The confusion matrices for each period can be found in Appendix A. The results showed that the landscape of the study area has undergone continuous temporal and spatial changes that have transformed its structure and configuration (Figure 2). During the first period (1985-2000), the most notable changes were a $6 \%(50,738$ ha) increase in the overall proportion of landscape under agriculture and a 3.9\% (31,165 ha) decrease in the overall proportion of native vegetation (Figure 3). Additionally, during this period, $41.2 \%$ of dense Caatinga changed to open Caatinga, and $2.6 \%$ changed to agricultural land (Figure 4 ). In addition, $12.8 \%$ of open Caatinga was converted to pasture and $5.8 \%$ to agricultural land (Figure 4). In the second studied period (2000-2018), the most noteworthy changes were a decrease of $16.4 \%$ in the overall proportion of open and dense Caatinga and an increase of $12.7 \%$ in pasture (Figure 3 ). In this period, $60.6 \%$ of dense Caatinga changed to open Caatinga, $4.9 \%$ changed to pasture and $2.5 \%$ changed to agricultural land (Figure 4 ). A total of $29.9 \%$ of open Caatinga was also converted to pasture and $5.2 \%$ to agricultural land (Figure 4).

\subsection{Fragmentation Process in Open and Dense Caatinga}

Dense Caatinga experienced greater fragmentation than open Caatinga between 1985-2018, as its number of patches increased by $85 \%$, while the number of open Caatinga patches increased by $28.6 \%$ (Table 1 ). The largest patch index of the dense Caatinga patch decreased by 14.9\% between 1985 and 2018, which suggests that the surface area of the largest dense Caatinga patch decreased in size by that amount (Table 1). In contrast, the largest patch index of open Caatinga increased by $5.3 \%$ (Table 1 ). The mean area of dense and open Caatinga patches decreased by $84.8 \%$ and $6.1 \%$, respectively, between 1985 and 2018 (Table 1). Finally, the mean Euclidean nearest neighbor distance for dense Caatinga increased by $15.8 \%$ between 1985 and 2018 and decreased by $7.2 \%$ for open Caatinga (Table 1).

\subsection{Determining the Connectivity Distance Threshold}

For dense Caatinga, it was found that the distances showing the greatest change in IIC and CCP values were 100, 560 and $1140 \mathrm{~m}$ (Figure 5a,b). These distances were selected to conduct an ex-post analysis, as they cover a wide range of responses by different species to the landscape pattern [64-66].

\subsection{Changes in Connectivity under Projections of Agricultural Expansion}

In the hypothetical projection, where agricultural patches increased by a buffer of $100 \mathrm{~m}$, a loss in connectivity of approximately $2 \%$ was observed for dispersal distances of 100, 560 and $1140 \mathrm{~m}$ (Figure 6). In contrast, connectivity for the dispersal distance of $20,000 \mathrm{~m}$ was reduced by $5.8 \%$ (Figure 6). When agricultural land increased by a $200 \mathrm{~m}$ buffer, the four smaller dispersal distances experienced a loss in connectivity of approximately $4 \%$ (Figure 6) and the 20,000 m dispersal distance reduced its connectivity by $10.8 \%$ (Figure 6 ). In the last projection (300 $\mathrm{m}$ buffer), the loss of connectivity ranged from approximately 5\% to 6\% for the 100, 560 and $1140 \mathrm{~m}$ dispersal distances (Figure 6), whilst the connectivity reduced by $15 \%$ for the $20,000 \mathrm{~m}$ dispersal distance (Figure 6). 


\section{(a) 1985}

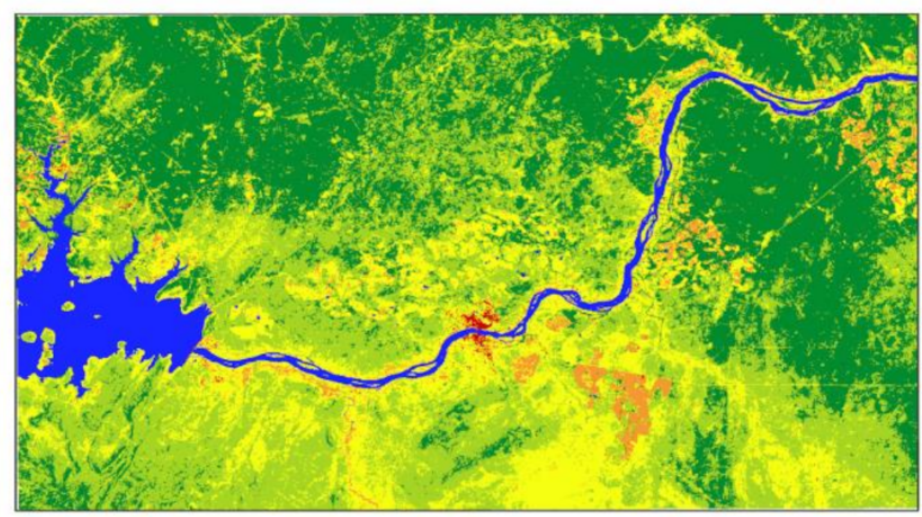

\section{(b) 2000}

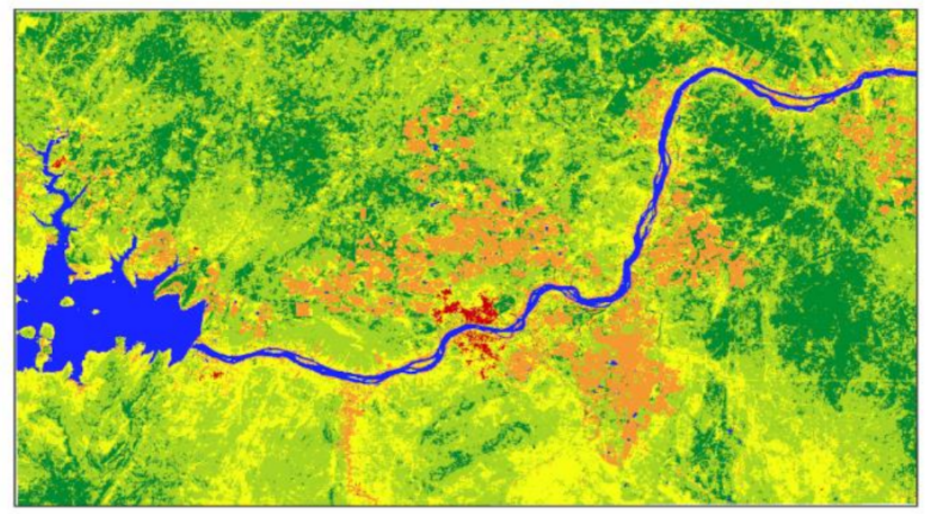

\section{(c) 2018}
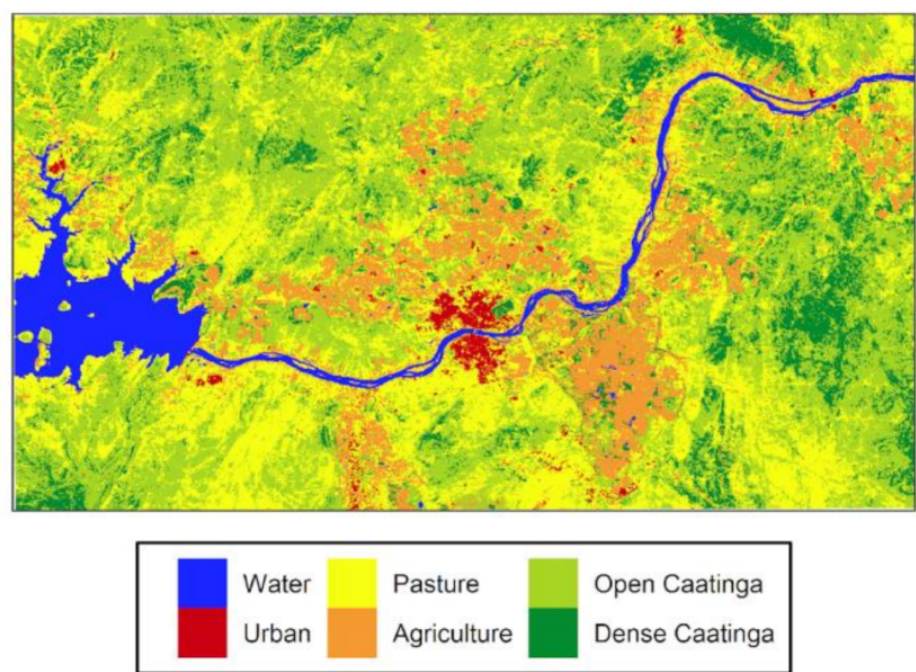

Figure 2. Changes in the landscape composition of the study area for the years: (a) 1985, (b) 2000 and (c) 2018 .

\subsection{Identified Patches for Conservation and Restoration}

The results of the prioritization to conserve patches of dense Caatinga for the selected distances showed that under both evaluated scenarios, the patches with the highest priority for conservation were concentrated in Juazeiro $\left(9.4^{\circ} \mathrm{S}, 40.1^{\circ} \mathrm{W}\right)$ (Figure 7$)$. In the first scenario, $3 \%$ (1849 ha) of the patches had conservation priority values greater than 0.6 , compared to $11.9 \%$ (7362 ha) of patches in the second (Figure 1, Appendix C). The results of the prioritization to restore patches of open Caatinga found, under both scenarios, that 
the highest number of patches to be restored was located around Petrolina $\left(9.1^{\circ} \mathrm{S}, 40.7^{\circ} \mathrm{W}\right)$ (Figure 7). In the first scenario, $3.4 \%(12,210 \mathrm{ha})$ of the patches had restoration priority values greater than 0.6 , compared to $10.8 \%(38,471 \mathrm{ha})$ of the patches in the second scenario (Figure 1, Appendix C).

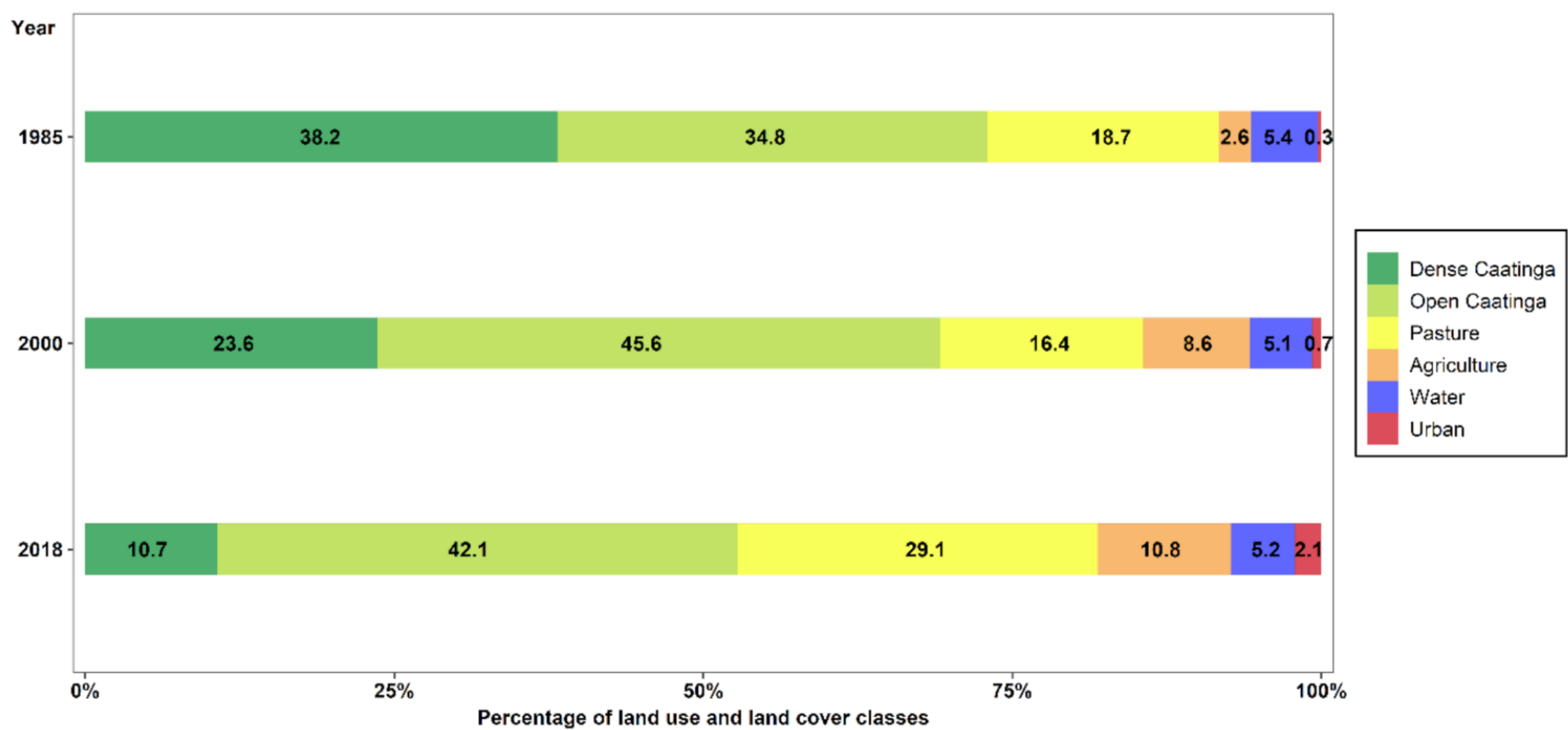

Figure 3. Comparison of the respective extents of land use/land cover classes by percentage of study area (study area = 846,400 ha).

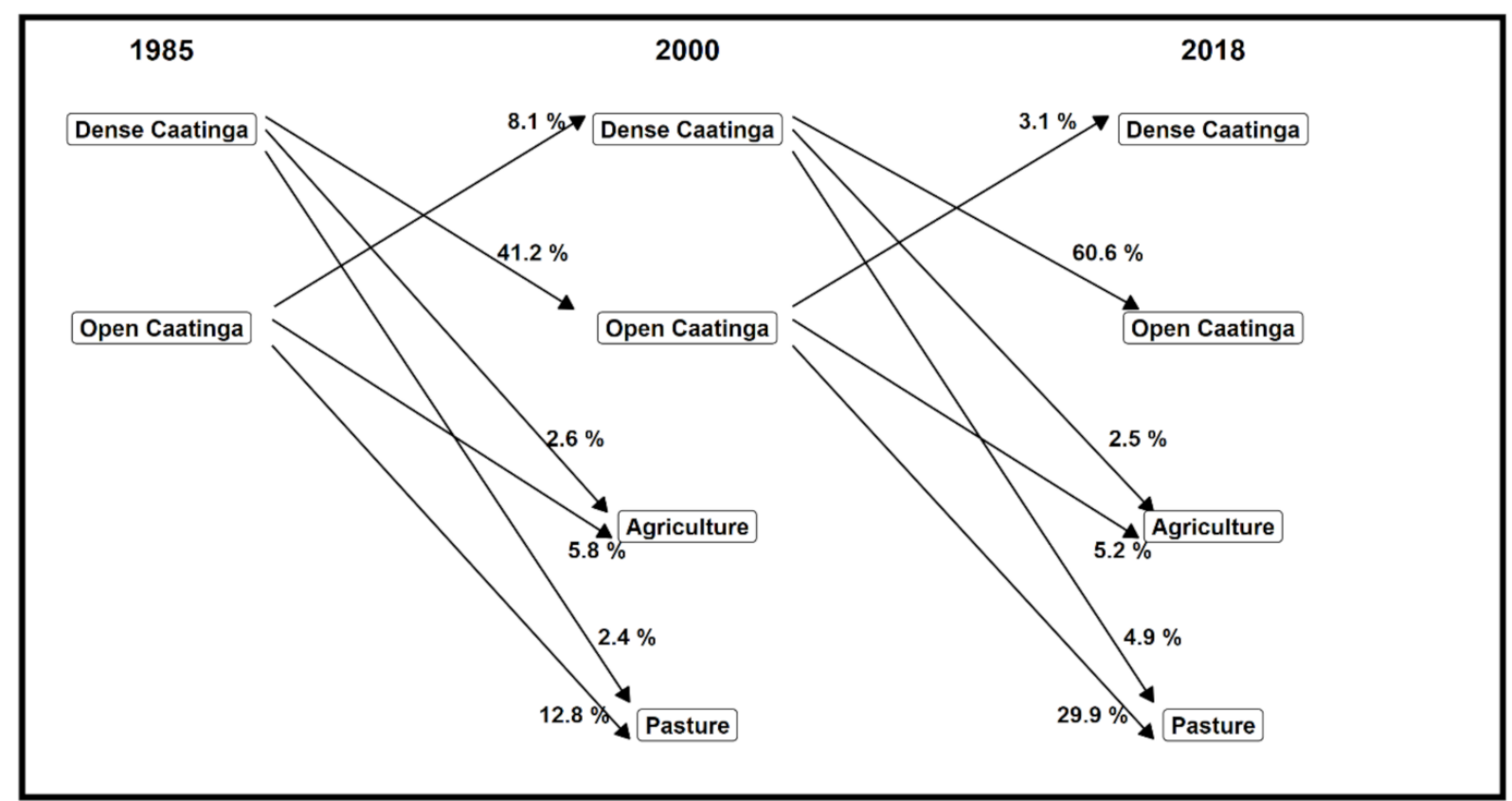

Figure 4. Major change trajectories and their contributions to net change in percentage of the study area. 
Table 1. Changes in landscape pattern indices for the native vegetation in the study area in 1985, 2000, and 2018.

\begin{tabular}{ccccccccc}
\hline & \multicolumn{3}{c}{ Dense Caatinga } & \multicolumn{5}{c}{ Open Caatinga } \\
\hline Landscape Indices & $\mathbf{1 9 8 5}$ & $\mathbf{2 0 0 0}$ & $\mathbf{2 0 1 8}$ & $\begin{array}{c}\text { \% Change } \\
\mathbf{( 1 9 8 5 - 2 0 1 8 )}\end{array}$ & $\mathbf{1 9 8 5}$ & $\mathbf{2 0 0 0}$ & $\mathbf{2 0 1 8}$ & $\begin{array}{c}\text { \% Change } \\
\mathbf{( 1 9 8 5 - 2 0 1 8 )}\end{array}$ \\
\hline $\begin{array}{c}\text { Number of patches } \\
\text { Largest patch index (\%) }\end{array}$ & 7670 & 11,263 & 14,208 & $85.2 \%$ & 11,309 & 9895 & 14,546 & $28.6 \%$ \\
$\quad \begin{array}{c}\text { Mean patch area (ha) } \\
\text { Mean Euclidean nearest }\end{array}$ & 42.2 & 17.8 & 6.4 & $-84.8 \%$ & 26.1 & 39.1 & 24.5 & $-6.1 \%$ \\
neighbor distance (m) & 128.6 & 130.6 & 148.9 & $15.8 \%$ & 114.9 & 102.6 & 106.6 & $-7.2 \%$ \\
\hline
\end{tabular}

(a)

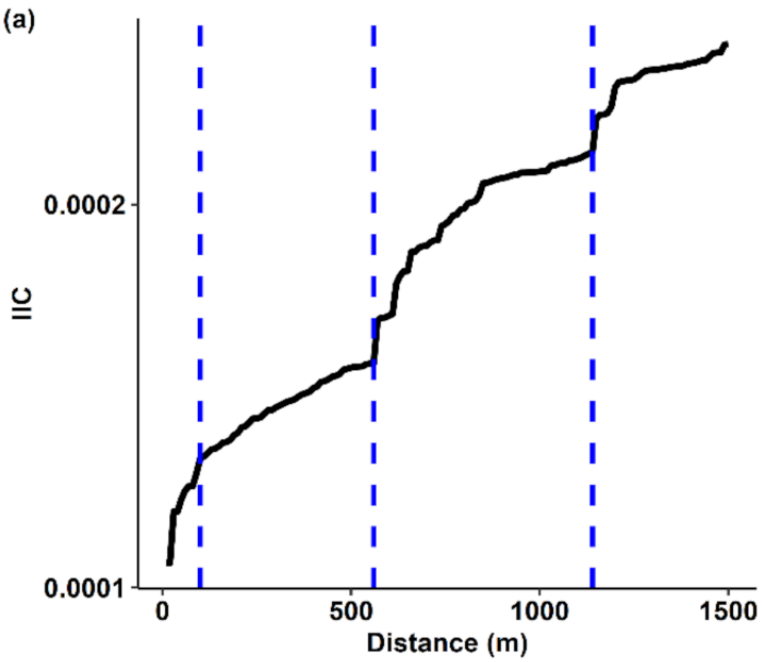

(b)

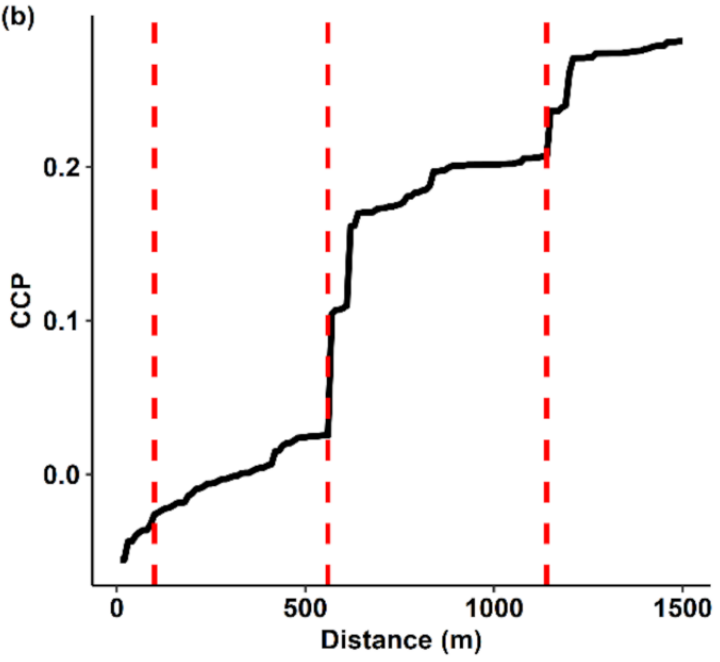

Figure 5. IIC (a) and CCP (b) values for connectivity distances from 10 to $1500 \mathrm{~m}$. Based on these data, the connectivity distances used for the subsequent analysis were set at 100, 560 and $1140 \mathrm{~m}$ for dense Caatinga (shown in dashed lines).

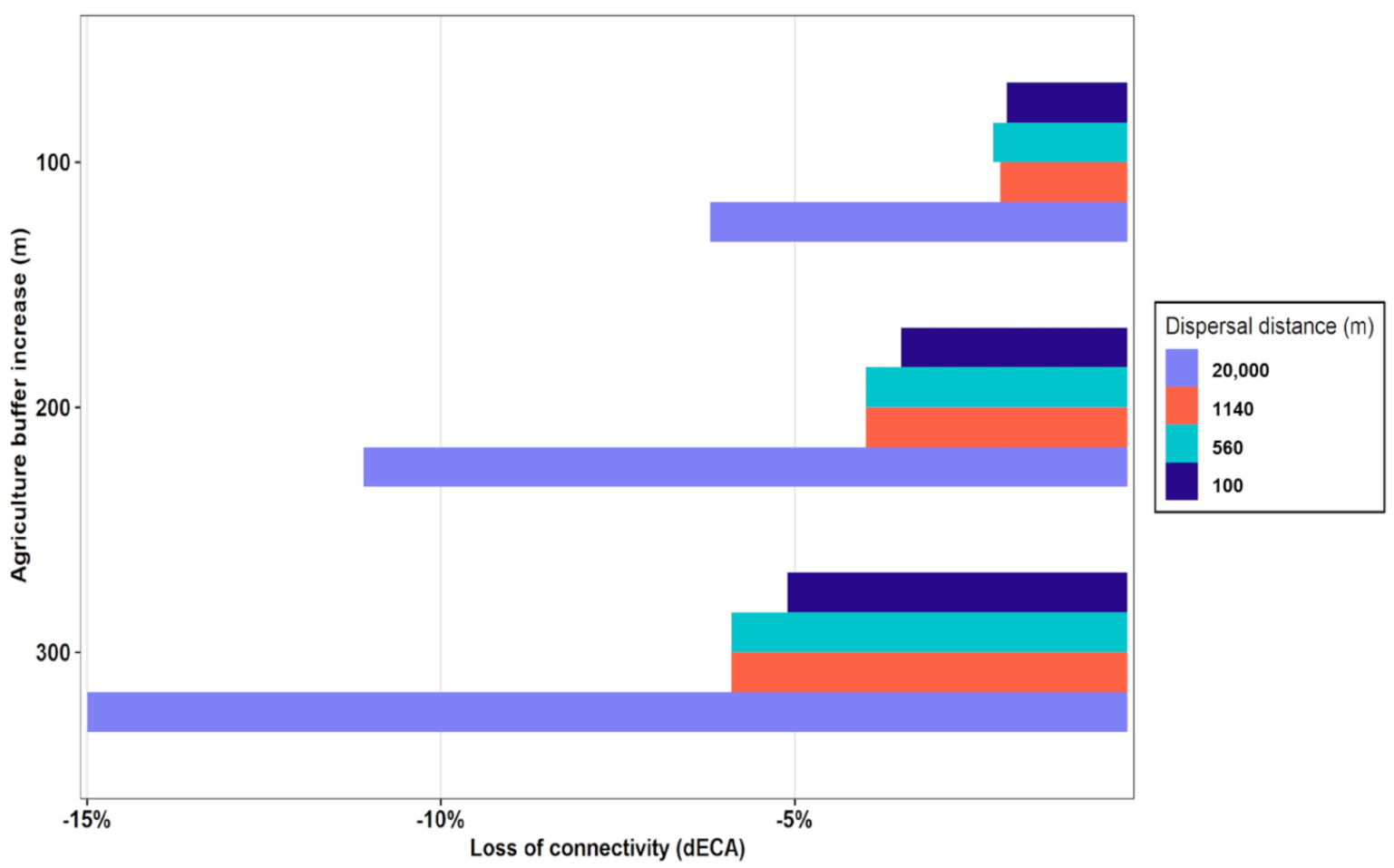

Figure 6. Relative changes (\%) in connectivity ( $d E C A)$ given by the effect of the hypothetical increase in agricultural area in the studied landscape, given different dispersal distances used to calculate connectivity. 
(a)

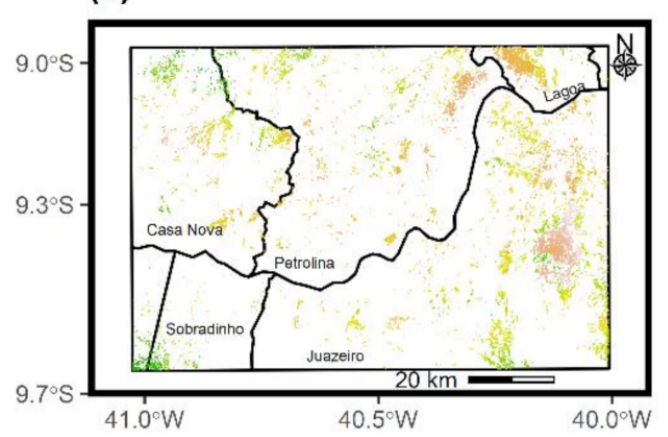

(c)

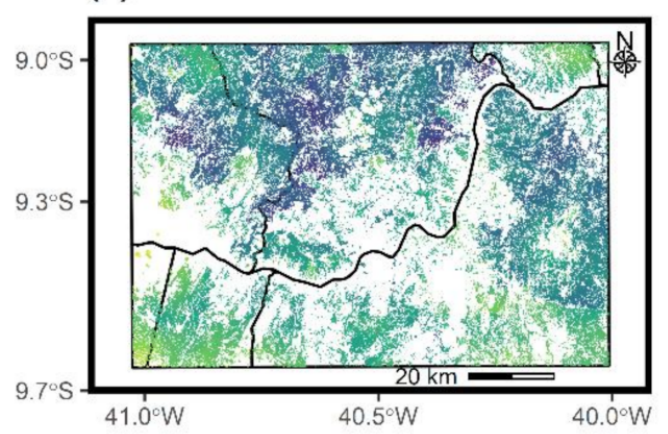

(b)

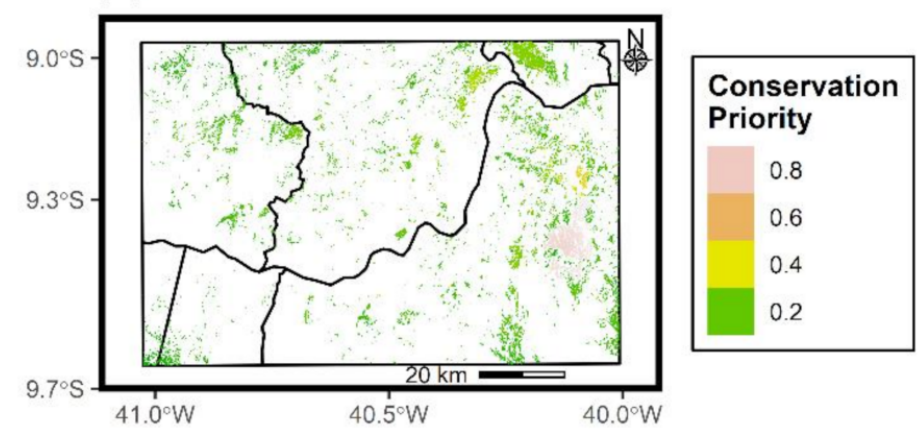

(d)

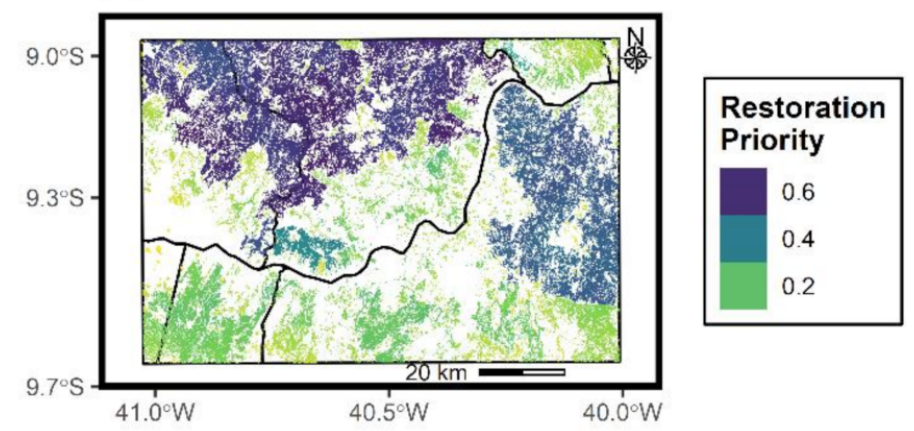

Figure 7. Conservation priorities of dense Caatinga patches for the different scenarios of index weightings in the MCDA: (a) Scenario 1, (b) scenario 2. Restoration priorities of open Caatinga patches for the different scenarios of index weightings in the MCDA: (c) Scenario 1, (d) scenario 2. Scenario 1 corresponded to the weights $0.6,0.2$ and 0.2 for CDI, dIIC and BC, respectively, and scenario 2 corresponded to the weights $0.2,0.4$ and 0.4 for CDI, dIIC and $B C$, respectively. The black lines represent the boundaries of the administrative units.

\section{Discussion}

Our study showed a steady increase in agricultural land in the studied landscape, with Caatinga's native vegetation being the most negatively affected. This change is the result of landscape fragmentation, where areas of dense Caatinga have become fragmented ( $85.2 \%$ increase in the number of patches) and decreased in average size (by $84.8 \%$, from 42.2 ha in 1985 to 6.4 ha in 2018). The LULC change patterns found in this study are similar to those reported by other authors for the same biome [7,80-82] and similar to other seasonally dry areas, such as the Mediterranean landscapes in Turkey [83], semi-arid zones in Chile [56], and native forests in Mexico [84]. It is important to consider that open Caatinga patches within the studied area have large tracts of disturbed edges, which have liken arisen due to chronic anthropogenic disturbance through agricultural expansion, overgrazing or harvesting timber $[33,34]$, and are likely to be at further increased risk of habitat conversion to pasture and agriculture [35].

By selecting a range of dispersal distances (from $100 \mathrm{~m}$ to 20,000 m), we showed that connectivity indices varied according to species' dispersal abilities $[21,59,85]$. The distances we calculated empirically, based on the behavior of graph-based connectivity indices for our landscape, were similar to the published dispersal distances of animals which are found in the study area. The species present in our study area have different habitat requirements, which could vary between the rainy and dry seasons, as well as with the distance to urban areas and with edge quality, etc. [86]. Even so, we believe that our calculated connectivity indices represent meaningful scales for the medium-sized mammals and reptiles that have been recorded in the study landscape.

The three projections of agricultural expansion (100, 200 and $300 \mathrm{~m}$ increase in area around 2018 agriculture) had varying impacts on landscape connectivity and are likely to af- 
fect species differently, depending on their dispersal ability (Figure 6). For H. yagouaroundi, the connectivity reduction was approximately $6-15 \%$ under our agricultural class expansion projections, as its long-term persistence and viability requires large, interconnected habitats [72]. A landscape fragmentation analysis conducted in the southern Amazonia showed that the minimum vegetation patch size required by H. yagouaroundi is about 790 ha [70]. Patches of this size are scarce in our study area, further decreasing the landscape connectivity for this feline, meaning that maintaining and increasing patch connectivity and conserving the suitable habitat will be key for its persistence.

Decreases in connectivity in response to agricultural expansion were assumed to be smaller for species with shorter dispersal distances, which were based on the published literature, and our findings found reductions in connectivity for these species to be between approximately $2 \%$ and $6 \%$ (Figure 6). These decreases in connectivity may have negative consequences for T. hispidus due to its low dispersal capacity [67]. Defining priority native vegetation patches for conservation and restoration, using the dispersal distance of $H$. yagouaroundi as a reference, could potentially provide protection for other coexisting species, as we expect $H$. yagouaroundii's requirements to be the largest [87]. These results can be used to make spatial and territorial planning decisions [7], where, depending on the different scenarios, it can be decided whether to favor increasing connectivity, or minimizing potential anthropogenic threats, or both.

We used MCDA to prioritize habitat patches for the conservation of dense Caatinga or the restoration of open Caatinga, using two scenarios, which differed according to the relative weighting assigned to each index of connectivity or disturbance at the scale of habitat patches (Figure 7). In the first scenario, which gave a higher weighting to the CDI, patches with the highest prioritization values were immersed in the agricultural matrix and were very large, so they were the most exposed to agricultural management [64]. Vegetation patches close to the agricultural matrix may, in some cases, provide resources for certain species [88], such as H. yagouaroundi, which has been observed in agricultural areas [89] where there is a high abundance of prey [72]. In the second scenario, most of the patches had low prioritization values since the contribution to connectivity of most of the patches was low. Nevertheless, the first scenario suggested a higher number of patches as being important for restoration, indicating that restoration should happen mostly within open Caatinga patches, which are characterized by being degraded by agricultural activities, high grazing pressure and clear cuts within our studied area. These degraded open Caatinga patches around agricultural areas are large and widely distributed throughout the study area [34], thus, restoring them to promote the growth of native herbaceous species and higher vegetation coverage and density could prove beneficial for biodiversity [7], as large patches can conserve species with large populations [90], maintain a higher number of species [64] and provide a high-quality interior habitat [91]. Furthermore, as the mean Euclidean distance between open Caatinga patches was smaller than that of dense Caatinga patches ( $106.6 \mathrm{~m}$ vs. $148.9 \mathrm{~m})$, restoring these patches could increase landscape connectivity [7]. In agreement with our results, recent studies showed that disturbed Caatinga vegetation fragments, such as the open Caatinga within our study area, still maintain a reasonable structural integrity but have been heavily exposed to anthropogenic pressure in recent decades [26,35], reinforcing the need for landscape planning for conservation and restoration [34].

Agricultural expansion made possible by irrigation, and increases in areas grazed as pastures, both of which are linked to increased urbanization, pose a constant threat to the Caatinga biome. Even though Brazil establishes a regulatory framework for agricultural expansion [18,92], the intensification of agriculture in both size and agrochemical use adversely impacts biodiversity [93]. In addition, sheep-based subsistence livestock farming in which animals are allowed to breed freely and feed on native vegetation are degrading the Caatinga and weakening ecosystem resilience $[33,94]$. These factors could account for the increase in pastures and the decrease in native vegetation observed in the study area 
in the São Francisco Valley. Landscape planning policies that include society and its local context are key to achieving sustainable development in the region [95].

Our results should be interpreted considering their limitations. One possible criticism of our analysis is that we assume that open Caatinga, within the study area, is open because of degradation primarily caused by contemporary overgrazing. An alternative perspective is that open Caatinga, maintained by herbivory, is a 'natural' state. This alternative perspective is supported by the observation that some Caatinga species assemblies contain many species, which are shared with other South American dry open forests and savannahs, such as the Argentinian Chaco [28,96]. However, despite such biogeographic considerations, we point to studies that relate contemporary human activities with Caatinga degradation in areas surrounded by agriculture $[26,33]$ and expansion of invasive species associated with livestock pressures [93]. It is, therefore, important to note that there is no evidence that suggests that a 'natural', open Caatinga would biologically resemble the degraded conditions that are common around farmland and other human-disturbed areas. Nevertheless, it is important to caveat our conclusions that in some settings, and for some species groups, it may be preferable to restore degraded Caatinga to an open-structured condition, and that in those circumstances, herbivory may play an important role.

The selected studied area only encompasses one large area of Caatinga, which is characterized by strong agricultural pressure, thus our results may not be applicable to the whole of Caatinga and may have been different had we studied the whole biome. Our results should be taken as showing key patterns and trends, as the exact proportions of land changes may be associated with errors. For example, in the early 1980s, agricultural expansion rates were high, standing at 10,500 ha/year across the entire São Francisco Valley [97], while our results from the first study period show an increase of 3382 ha/year. Another potential limitation is that the land cover categories used in this study are based on geographic information systems (www.mapbiomas.org, accessed on 20 April 2021) and some categories, such as pastures, could include native herbs as part of its community, but the scale of the study does not allow to differentiate this level of detail. Thus, despite these limitations, we present trends that coincide with those from other studies [33,94] and that contribute to the knowledge of this area by considering both the historical and connectivity analysis for spatial and territorial planning. We believe that our results can inform the work of restoration ecologists and policymakers who can further build on these results to develop local and specific conservation goals for sustainable agriculture.

Our results show that vegetation fragments close to agricultural land play a fundamental role in landscape connectivity, acting as stepping-stones and increasing connectivity at the landscape level [64]. The restoration and conservation priorities proposed in this study have the long-term potential to be used as a conservation strategy in the Caatinga [34]. In this way, other studies have shown that the quality of the overall agricultural landscape can be enhanced for the species that live in the remnant habitat, patched via crop diversification and through increased connectivity, indicating a complementary strategy for the São Francisco Valley $[17,18,98]$.

It has been suggested that sustainable agricultural landscapes in dry tropical regions, such as this study area, should have at least $50 \%$ natural vegetation to deliver an optimum mix of essential ecosystem services [99]. Although our study area still has a large amount of native vegetation (52.8\%) remaining, we have identified historical trends in LULC change consistent with increases in livestock farming, which other studies have shown to have the potential to degrade even large remnant patches of the Caatinga $[26,35,100]$. If the native vegetation in the study area continues to decline, the degradation of this semi-arid ecosystem could become more severe $[7,26,99]$.

\section{Conclusions}

The unique biodiversity of the Caatinga biome requires urgent actions to promote the conservation and restoration of the remnants of the degraded dry forest. We showed that the recent change in LULC between 1985 and 2018 caused habitat loss and fragmentation 
in the studied Caatinga area in the São Francisco Valley in the Northeast of Brazil. Irrigated agriculture, through indirect conversion (conversion from dense Caatinga to open and then to agricultural land) and direct conversion (Caatinga to agricultural land) are the main causes of the recent land-use change. Fragmentation and loss of connectivity impact species differently according to their dispersal distances and may affect ecosystem functionality. Our analyses showed that, despite the fragmentation of the studied landscape, patches can still be functional for connectivity purposes. We explicitly identified zones that support connectivity for conservation and restoration planning in the area. The results support conservation strategies that aim to increase landscape-scale connectivity for biodiversity and highlight the importance of the Caatinga remnants in the study area's expanding agricultural matrix. The recent agricultural development in the São Francisco Valley needs to achieve sustainable landscape management. Our study provides quantified information that should be used to inform long-term goal planning and to co-produce integrated farm interventions.

Author Contributions: Conceptualization, A.A.S., E.C.A., A.M.-S., M.D.M., N.B.Z., L.V.D.; methodology, A.A.S., E.C.A., A.M.-S., M.D.M.; software, A.A.S.; validation, A.A.S., E.C.A., A.M.-S., M.D.M., F.O.d.S., N.B.Z., L.P.C., V.S.-F., P.O.-R. and L.V.D.; formal analysis, A.A.S., E.C.A., A.M.-S.; investigation and resources, A.A.S., E.C.A., A.M.-S., M.D.M., F.O.d.S., N.B.Z., L.P.C., V.S.-F., P.O.-R. and L.V.D.; writing-original draft preparation, A.A.S., E.C.A., A.M.-S., M.D.M.; writing-review and editing, A.A.S., E.C.A., A.M.-S., M.D.M., F.O.d.S., N.B.Z., L.P.C., V.S.-F., P.O.-R. and L.V.D.; supervision, E.C.A., A.M.-S.; funding acquisition, E.C.A., L.V.D. All authors have read and agreed to the published version of the manuscript.

Funding: This research was funded by the Nexus project initiative from Newton Fund/BBSRC project code BB/R016429/1 and ANID project NEXUS code FONDEF BB/R0164291, and Center of Applied Ecology and Sustainability (CAPES) project code PIA/BASAL FB0002.

Data Availability Statement: Publicly available datasets were analyzed in this study. These data can be found here: github.com/andrestyle16/lulc_caatinga, accessed on 30 April 2021.

Acknowledgments: E.C.A. acknowledge the support from the project ANID/PIA/act192027, F.O.d.S. the support from CNPq/CAPES/INCT IN-TREE (chamada INCT-MCTI/CNPq/FAPs n 16/2014), and N.B.Z. the support from UKRI BBSRC Norwich Research Park Biosciences Doctoral Training Partnership.

Conflicts of Interest: The authors declare no conflict of interest.

Appendix A. Confusion Matrix

Table A1. Confusion matrix year 1985.

\begin{tabular}{cccccccc}
\hline Class & Water & Urban & Pasture & Agriculture & $\begin{array}{c}\text { Open } \\
\text { Caatinga }\end{array}$ & $\begin{array}{c}\text { Dense } \\
\text { Caatinga }\end{array}$ & Total \\
\hline Water & 47 & 0 & 1 & 0 & 0 & 2 & 50 \\
Urban & 0 & 35 & 13 & 2 & 0 & 0 & 50 \\
Pasture & 0 & 1 & 48 & 1 & 0 & 0 & 50 \\
Agriculture & 0 & 1 & 8 & 40 & 0 & 1 & 50 \\
$\begin{array}{c}\text { Open } \\
\text { Caatinga }\end{array}$ & 0 & 0 & 2 & 0 & 43 & 7 & 52 \\
$\begin{array}{c}\text { Dense } \\
\text { Caatinga }\end{array}$ & 0 & 0 & 0 & 0 & 0 & 50 & 50 \\
Total & 47 & 37 & 72 & 43 & 43 & 60 & 302 \\
\hline
\end{tabular}


Table A2. Confusion matrix year 2000.

\begin{tabular}{|c|c|c|c|c|c|c|c|}
\hline Class & Water & Urban & Pasture & Agriculture & $\begin{array}{c}\text { Open } \\
\text { Caatinga }\end{array}$ & $\begin{array}{c}\text { Dense } \\
\text { Caatinga }\end{array}$ & Total \\
\hline Water & 55 & 0 & 0 & 1 & 1 & 3 & 60 \\
\hline Urban & 0 & 50 & 14 & 1 & 0 & 0 & 65 \\
\hline Pasture & 0 & 0 & 53 & 0 & 4 & 0 & 57 \\
\hline Agriculture & 1 & 0 & 6 & 82 & 0 & 0 & 89 \\
\hline $\begin{array}{l}\text { Open } \\
\text { Caatinga }\end{array}$ & 0 & 0 & 1 & 1 & 47 & 1 & 50 \\
\hline $\begin{array}{l}\text { Dense } \\
\text { Caatinga }\end{array}$ & 0 & 0 & 0 & 0 & 8 & 42 & 50 \\
\hline Total & 56 & 50 & 74 & 85 & 60 & 46 & 371 \\
\hline
\end{tabular}

Table A3. Confusion matrix year 2018.

\begin{tabular}{cccccccc}
\hline Class & Water & Urban & Pasture & Agriculture & $\begin{array}{c}\text { Open } \\
\text { Caatinga }\end{array}$ & $\begin{array}{c}\text { Dense } \\
\text { Caatinga }\end{array}$ & Total \\
\hline Water & 175 & 0 & 0 & 4 & 0 & 0 & 179 \\
Urban & 0 & 83 & 12 & 0 & 1 & 0 & 96 \\
$\begin{array}{c}\text { Pasture } \\
\text { Agriculture }\end{array}$ & 0 & 0 & 124 & 4 & 2 & 0 & 130 \\
$\begin{array}{c}\text { Open } \\
\text { Caatinga }\end{array}$ & 0 & 0 & 19 & 0 & 93 & 1 & 159 \\
$\begin{array}{c}\text { Dense } \\
\text { Caatinga }\end{array}$ & 0 & 0 & 0 & 0 & 26 & 120 & 146 \\
Total & 175 & 83 & 163 & 156 & 124 & 122 & 823 \\
\hline
\end{tabular}

\section{Appendix B}

Table A4. Land use/land cover type estimated (ha) for 1985, 2000 and 2018 in the study area.

\begin{tabular}{ccccc}
\hline Class & $\mathbf{1 9 8 5}$ & $\mathbf{2 0 0 0}$ & $\mathbf{2 0 1 8}$ & $\begin{array}{c}\text { Net Change } \\
\mathbf{( 1 9 8 5 - 2 0 1 8 )}\end{array}$ \\
& ha & ha & ha & ha \\
\hline Water & 45,894 & 43,323 & 44,700 & -1193 \\
Urban & 2747 & 5924 & 17,439 & 14,692 \\
Pasture & 157,942 & 137,763 & 247,296 & 89,354 \\
Agriculture & 22,344 & 73,082 & 91,793 & 69,449 \\
Open Caatinga & 294,539 & 386,705 & 355,839 & 61,300 \\
Dense Caatinga & 323,650 & 200,319 & 90,637 & $-233,012$ \\
\hline
\end{tabular}

Table A5. Agriculture area for the different projections of agriculture expansion.

\begin{tabular}{ccc}
\hline Stage & Agriculture Area (ha) & \% Agriculture Area Compared to 2018 \\
\hline Year 185 & 22,344 & -75.7 \\
Year 2000 & 73,082 & -20.4 \\
Year 2018 & 91,793 & - \\
Projection 1 & 97,466 & +6.2 \\
Projection 2 & 101,854 & +10.9 \\
Projection 3 & 105,145 & +14.5 \\
\hline
\end{tabular}




\section{Appendix C}

a)

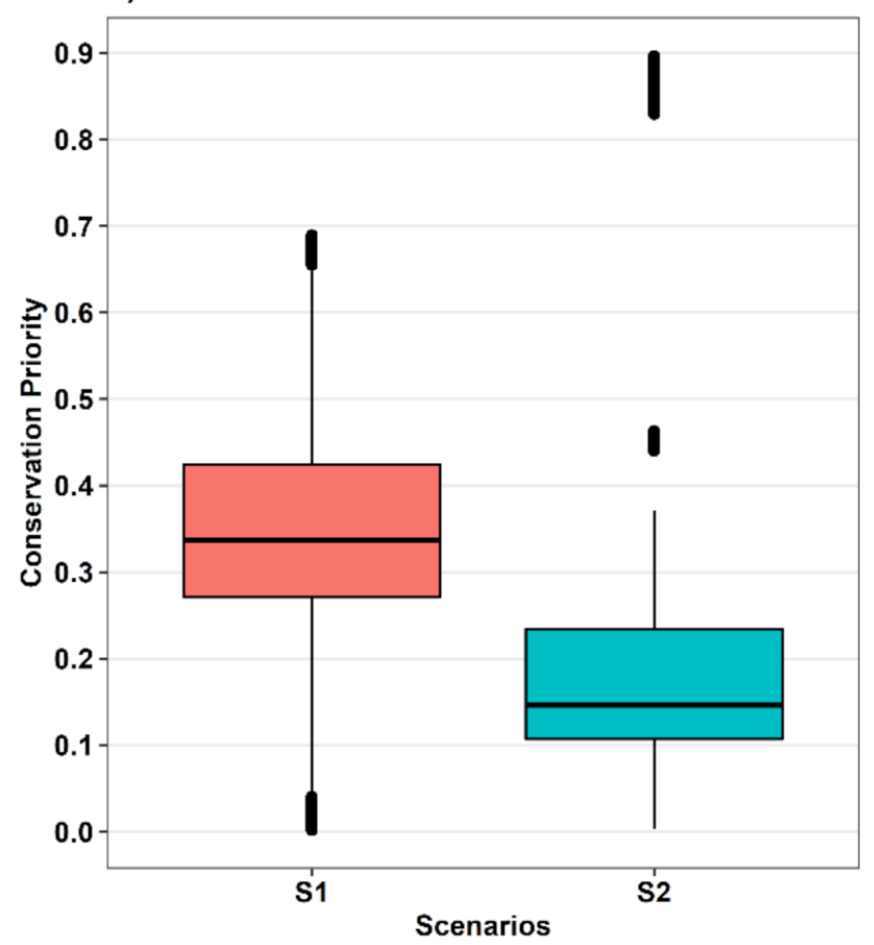

b)

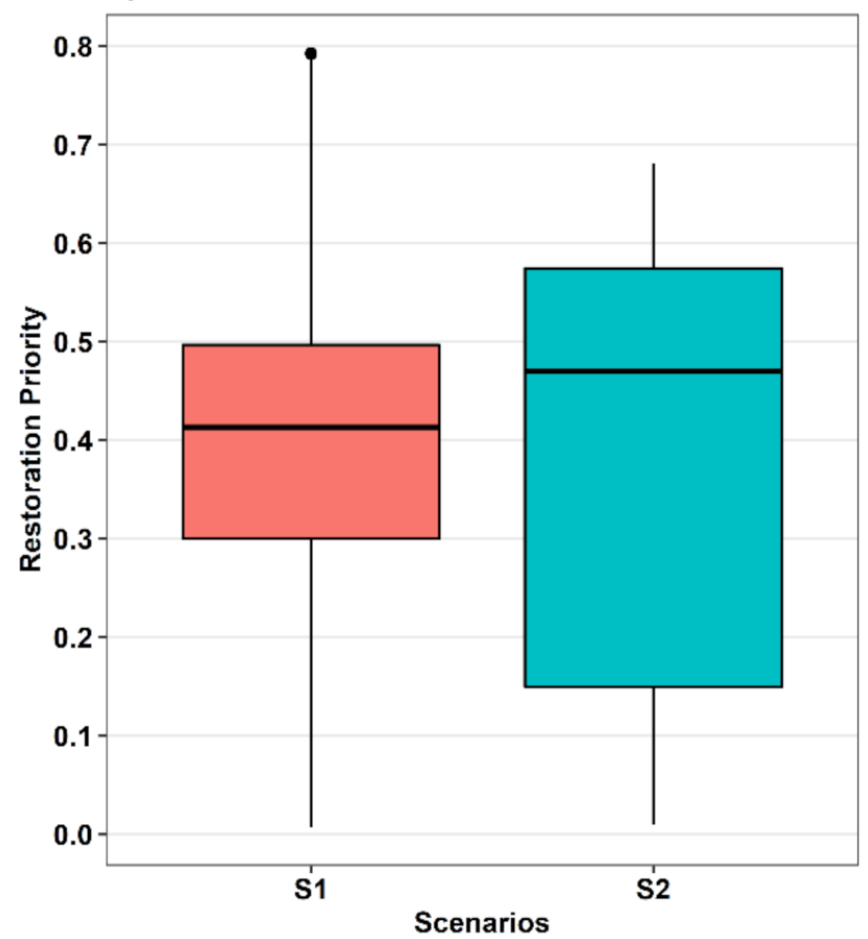

Figure 1. Distribution of (a) conservation priority values and (b) restoration priority values for the different scenarios.

\section{References}

1. Newbold, T.; Hudson, L.N.; Hill, S.L.L.; Contu, S.; Lysenko, I.; Senior, R.A.; Börger, L.; Bennett, D.J.; Choimes, A.; Collen, B.; et al. Global effects of land use on local terrestrial biodiversity. Nature 2015, 520, 45-50. [CrossRef]

2. Song, X.-P.; Hansen, M.C.; Stehman, S.V.; Potapov, P.V.; Tyukavina, A.; Vermote, E.F.; Townshend, J.R. Global land change from 1982 to 2016. Nature 2018, 560, 639-643. [CrossRef]

3. Hansen, M.C.; Potapov, P.V.; Moore, R.; Hancher, M.; Turubanova, S.A.; Tyukavina, A. High-Resolution Global Maps. Science 2013, 134, 850-854. [CrossRef]

4. Santos, C.A.G.; Nascimento, T.V.M.D.; Da Silva, R.M. Analysis of forest cover changes and trends in the Brazilian semiarid region between 2000 and 2018. Environ. Earth Sci. 2020, 79. [CrossRef]

5. Laurance, W.F.; Sayer, J.; Cassman, K.G. Agricultural expansion and its impacts on tropical nature. Trends Ecol. Evol. 2014, 29, 107-116. [CrossRef]

6. Maxwell, S.L.; Fuller, R.A.; Brooks, T.M.; Watson, J.E.M. Biodiversity: The ravages of guns, nets and bulldozers. Nature 2016, 536, 143-145. [CrossRef]

7. Antongiovanni, M.; Venticinque, E.M.; Fonseca, C.R. Fragmentation patterns of the Caatinga drylands. Landsc. Ecol. 2018, 33, 1353-1367. [CrossRef]

8. Haddad, N.M.; Brudvig, L.A.; Clobert, J.; Davies, K.F.; Gonzalez, A.; Holt, R.D.; Lovejoy, T.E.; Sexton, J.O.; Austin, M.P.; Collins, C.D.; et al. Habitat fragmentation and its lasting impact on Earth's ecosystems. Sci. Adv. 2015, 1, e1500052. [CrossRef] [PubMed]

9. Schulz, J.J.; Cayuela, L.; Echeverria, C.; Salas, J.; Benayas, J.M.R. Monitoring land cover change of the dryland forest landscape of Central Chile (1975-2008). Appl. Geogr. 2010, 30, 436-447. [CrossRef]

10. Rudnick, D.; Ryan, S.J.; Beier, P.; Cushman, S.A.; Dieffenbach, F.; Epps, C.W.; Gerber, L.R.; Hartter, J.; Jenness, J.S.; Kintsch, J.; et al. The Role of Landscape Connectivity in Planning and Implementing Conservation and Restoration Priorities; Ecological Society of America: Washington, WA, USA, 2012.

11. Crooks, K.R.; Sanjayan, M. Connectivity Conservation: Maintaining Connections for Nature; Cambridge University Press (CUP): Cambridge, UK, 2006.

12. Hernández, A.; Miranda, M.; Arellano, E.C.; Saura, S.; Ovalle, C. Landscape dynamics and their effect on the functional connectivity of a Mediterranean landscape in Chile. Ecol. Indic. 2015, 48, 198-206. [CrossRef]

13. McClanahan, T.R.; Donner, S.D.; Maynard, J.A.; MacNeil, M.A.; Graham, N.A.J.; Maina, J.; Baker, A.C.; Alemu, J.B.; Beger, M.; Campbell, S.J.; et al. Prioritizing Key Resilience Indicators to Support Coral Reef Management in a Changing Climate. PLoS ONE 2012, 7, e0042884. [CrossRef] 
14. Saura, S.; Bodin, Ö.; Fortin, M.-J. Stepping stones are crucial for species' long-distance dispersal and range expansion through habitat networks. J. Appl. Ecol. 2014, 51, 171-182. [CrossRef]

15. Dos Santos, R.C.; Lima, M.; Junior, C.A.D.S.; Battirola, L.D. Disordered conversion of vegetation committees connectivity between forest fragments in the Brazilian Legal Amazon. Appl. Geogr. 2019, 111, 102082. [CrossRef]

16. De Fries, R.; Nagendra, H. Ecosystem management as a wicked problem. Science 2017, 356, 265-270. [CrossRef] [PubMed]

17. Kremen, C.; Merenlender, A.M. Landscapes that work for biodiversity and people. Science 2018, 362. [CrossRef]

18. Garibaldi, L.A.; Oddi, F.J.; Miguez, F.E.; Bartomeus, I.; Orr, M.C.; Jobbágy, E.G.; Kremen, C.; Schulte, L.A.; Hughes, A.C.; Bagnato, C.; et al. Working landscapes need at least 20\% native habitat. Conserv. Lett. 2021, 14, 1-10. [CrossRef]

19. Urban, D.; Keitt, T. Landscape connectivity: A graph-theoretic perspective. Ecology 2001, 82, 1205-1218. [CrossRef]

20. Pascual-Hortal, L.; Saura, S. Comparison and development of new graph-based landscape connectivity indices: Towards the priorization of habitat patches and corridors for conservation. Landsc. Ecol. 2006, 21, 959-967. [CrossRef]

21. Qi, K.; Fan, Z.; Ng, C.N.; Wang, X.; Xie, Y. Functional analysis of landscape connectivity at the landscape, component, and patch levels: A case study of Minqing County, Fuzhou City, China. Appl. Geogr. 2017, 80, 64-77. [CrossRef]

22. Volk, X.K.; Gattringer, J.P.; Otte, A.; Harvolk-Schöning, S. Connectivity analysis as a tool for assessing restoration success. Landsc. Ecol. 2018, 33, 371-387. [CrossRef]

23. Leal, I.R.; Da Silva, J.M.C.; Tabarelli, M.; Lacher, T.E. Changing the Course of Biodiversity Conservation in the Caatinga of Northeastern Brazil. Conserv. Biol. 2005, 19, 701-706. [CrossRef]

24. Velloso, A.L.; Sampaio, E.V.S.B.; Pareyn, F.G.C. Ecorregiões Propostas Para o Bioma Caatinga; The Nature Conservancy do Brasil: Recife, Brazil, 2002.

25. Serviço Florestal Brasileiro (SFB). Florestas do Brasil em Resumo-2013: Dados de 2007-2012; Serviço Florestal Brasileiro: Santarém, Brasil, 2013.

26. Ribeiro, E.M.S.; Arroyo-Rodríguez, V.; Santos, B.; Tabarelli, M.; Leal, I.R. Chronic anthropogenic disturbance drives the biological impoverishment of the Brazilian Caatinga vegetation. J. Appl. Ecol. 2015, 52, 611-620. [CrossRef]

27. De Queiroz, L.P.; Cardoso, D.; Fernandes, M.F.; Moro, M.F. Diversity and Evolution of Flowering Plants of the Caatinga Domain. In Caatinga: The Largest Tropical Dry Forest Region in South America; Springer: Berlin/Heidelberg, Germany, 2017 ; pp. $23-63$.

28. Bond, W.J. Open Ecosystems: Ecology and Evolution Beyond the Forest Edge; Oxford University Press: Oxford, UK, 2019.

29. Leal, I.; Tabarelli, M.; Silva, J.M.C.D. Ecologia e Conservação da Caatinga; Universidade Federal de Pernambuco: Recife, Brazil, 2003.

30. Koch, A.; Brierley, C.; Maslin, M.M.; Lewis, S.L. Earth system impacts of the European arrival and Great Dying in the Americas after 1492. Quat. Sci. Rev. 2019, 207, 13-36. [CrossRef]

31. Alves, R.R.; Mendonça, L.E.; Confessor, M.V.; Vieira, W.L.; Lopez, L.C. Hunting strategies used in the semi-arid region of northeastern Brazil. J. Ethnobiol. Ethnomed. 2009, 5, 12. [CrossRef] [PubMed]

32. Ferreira, T.R.; Da Silva, B.B.; De Moura, M.S.B.; Verhoef, A.; Nóbrega, R.L. The use of remote sensing for reliable estimation of net radiation and its components: A case study for contrasting land covers in an agricultural hotspot of the Brazilian semiarid region. Agric. For. Meteorol. 2020, 291, 108052. [CrossRef]

33. Marinho, F.P.; Mazzochini, G.G.; Manhães, A.P.; Weisser, W.W.; Ganade, G. Effects of past and present land use on vegetation cover and regeneration in a tropical dryland forest. J. Arid Environ. 2016, 132, 26-33. [CrossRef]

34. Da Silva, J.M.C.; Leal, I.R.; Tabarelli, M. Caatinga: The Largest Tropical Dry Forest Region in South America; Springer: Berlin/Heidelberg, Germany, 2018.

35. Antongiovanni, M.; Venticinque, E.M.; Matsumoto, M.; Fonseca, C.R. Chronic anthropogenic disturbance on Caatinga dry forest fragments. J. Appl. Ecol. 2020, 57, 2064-2074. [CrossRef]

36. De Espindola, G.M.; Figueredo, E.D.S.; Júnior, P.P.; Filho, A.A.D.R. Cropland expansion as a driver of land-use change: The case of Cerrado-Caatinga transition zone in Brazil. Environ. Dev. Sustain. 2021. [CrossRef]

37. Teixeira, A.H.D.C.; Leivas, J.F.; Andrade, R.G.; Hernandez, F.B.T.; Momesso, F.R.A. Modelling radiation and energy balances with Landsat 8 images under different thermohydrological conditions in the Brazilian semi-arid region. Remote Sens. Agric. Ecosystems. Hydrol. 2015, XVII, 96370U. [CrossRef]

38. Correia, M.F.; Dias, M.A.F.D.S.; Aragão, M.R.D.S. Soil occupation and atmospheric variations over Sobradinho Lake area. Part two: A regional modeling study. Theor. Appl. Clim. 2006, 94, 115-128. [CrossRef]

39. Selwyn, B. Globalized Horticulture: The Formation and Global Integration of Export Grape Production in North East Brazil. J. Agrar. Chang. 2010, 10, 537-563. [CrossRef]

40. Pearson, D. Key Roles for Landscape Ecology in Transformative Agriculture Using Aotearoa-New Zealand as a Case Example. Land 2020, 9, 146. [CrossRef]

41. Project MapBiomas-Collection 4.1 of Brazilian Land Cover \& Use Map Series. Available online: https://mapbiomas.org (accessed on 5 November 2020).

42. Roman, P. The São Francisco interbasin water transfer in Brazil: Tribulations of a megaproject through constraints and con-troversy. Water Altern. 2017, 10, 395-419.

43. Correia, M.F.; Dias, M.A.F.D.S.; Aragão, M.R.D.S. Soil occupation and atmospheric variations over Sobradinho Lake area. Part one: An observational analysis. Theor. Appl. Clim. 2006, 94, 103-113. [CrossRef]

44. De Jesus, J.B.; Kuplich, T.M.; Barreto, I.D.D.C.; Da Rosa, C.N.; Hillebrand, F.L. Temporal and phenological profiles of open and dense Caatinga using remote sensing: Response to precipitation and its irregularities. J. For. Res. 2021, 32, 1067-1076. [CrossRef] 
45. White, J.C.; Wulder, M.A.; Hobart, G.; Luther, J.; Hermosilla, T.; Griffiths, P.; Coops, N.; Hall, R.J.; Hostert, P.; Dyk, A.; et al. Pixel-Based Image Compositing for Large-Area Dense Time Series Applications and Science. Can. J. Remote Sens. 2014, 40, 192-212. [CrossRef]

46. Da Silva, J.L.B.; Bezerra, A.C.; Silva, T.T.F.; Batista, P.H.D.; Moura, G.B.D.A.; Lopes, P.M.O. Quantification Caatinga vegetable coverage and water availability by remote sensing in the Brazilian semiarid. J. Hyperspectral Remote Sens. 2019, 9, 166-176. [CrossRef]

47. Da Silveira, H.L.F.; Galvão, L.S.; Sanches, I.D.; De Sá, I.B.; Taura, T.A. Use of MSI/Sentinel-2 and airborne LiDAR data for mapping vegetation and studying the relationships with soil attributes in the Brazilian semi-arid region. Int. J. Appl. Earth Obs. Geoinf. 2018, 73, 179-190. [CrossRef]

48. The United States Geological Survey (USGS). Landsat 8 Surface Reflectance Code (LaSRC) Product; The United States Geological Survey: Reston, VG, USA, 2018.

49. The United States Geological Survey (USGS). Product Guide: Landsat Climate Data Record (CDR) Surface Reflectance; The United States Geological Survey: Reston, VG, USA, 2013.

50. Breiman, L. Random Forests. Mach. Learn. 2001, 45, 5-32. [CrossRef]

51. Parente, L.; Ferreira, L.; Faria, A.; Nogueira, S.; Araújo, F.; Teixeira, L.; Hagen, S. Monitoring the brazilian pasturelands: A new mapping approach based on the landsat 8 spectral and temporal domains. Int. J. Appl. Earth Obs. Geoinf. 2017, 62, 135-143. [CrossRef]

52. Reynolds, J.; Wesson, K.; Desbiez, A.L.J.; Ochoa-Quintero, J.M.; Leimgruber, P. Using Remote Sensing and Random Forest to Assess the Conservation Status of Critical Cerrado Habitats in Mato Grosso do Sul, Brazil. Land 2016, 5, 12. [CrossRef]

53. Andrade, E.M.; Valbrun, W.; De Almeida, A.M.M.; Rosa, G.; Da Silva, A.G.R. Land-Use Effect on Soil Carbon and Nitrogen Stock in a Seasonally Dry Tropical Forest. Agronomy 2020, 10, 158. [CrossRef]

54. Echeverria, C.; Coomes, D.; Salas, J.; Rey-Benayas, J.M.; Lara, A.; Newton, A. Rapid deforestation and fragmentation of Chilean Temperate Forests. Biol. Conserv. 2006, 130. [CrossRef]

55. Chuvieco, E. Teledetección Ambiental: La Observación de la Tierra Desde el Espacio; Ariel Ciencia: Barcelona, Spain, 2002.

56. Hernández, A.; Miranda, M.D.; Arellano, E.C.; Dobbs, C. Landscape trajectories and their effect on fragmentation for a Mediterranean semi-arid ecosystem in Central Chile. J. Arid Environ. 2016, 127, 74-81. [CrossRef]

57. R Core Team. R: A Language and Environment for Statistical Computing; R Foundation for Statistical Computing: Vienna, Austria, 2021.

58. Hesselbarth, M.H.K.; Sciaini, M.; With, K.A.; Wiegand, K.; Nowosad, J. Landscapemetrics: An open-source R tool to calculate landscape metrics. Ecography 2019, 42, 1648-1657. [CrossRef]

59. Cui, Y.; Xiao, R.; Zhang, M.; Wang, C.; Ma, Z.; Xiu, Y.; Wang, Q.; Guo, Y. Hydrological connectivity dynamics and conservation priorities for surface-water patches in the Yellow River Delta National Nature Reserve, China. Ecohydrol. Hydrobiol. 2020, 20. [CrossRef]

60. Estrada, E.; Bodin, Ö. Using network centrality measures to manage landscape connectivity. Ecol. Appl. 2008, 18, 1810-1825. [CrossRef]

61. Decout, S.; Manel, S.; Miaud, C.; Luque, S. Integrative approach for landscape-based graph connectivity analysis: A case study with the common frog (Rana temporaria) in human-dominated landscapes. Landsc. Ecol. 2012, 27, 267-279. [CrossRef]

62. Ayram, C.A.C.; Mendoza, M.E.; Salicrup, D.R.P.; Granados, E.L. Identifying potential conservation areas in the Cuitzeo Lake basin, Mexico by multitemporal analysis of landscape connectivity. J. Nat. Conserv. 2014, 22, 424-435. [CrossRef]

63. Chaves, I.D.B.; Lopes, V.; Ffolliott, P.; Paes-Silva, A.P. Uma Classificação Morfo-Estrutural Para Descrição E Avaliação da Biomassa da Vegetação da Caatinga a Morpho-Structural Classification for Description and Evaluation of the Biomass of the Caatinga Vegetation. Rev. Caatinga 2008, 12, 204-213.

64. Herrera, L.P.; Sabatino, M.C.; Jaimes, F.R.; Saura, S. Landscape connectivity and the role of small habitat patches as stepping stones: An assessment of the grassland biome in South America. Biodivers. Conserv. 2017, 26, 3465-3479. [CrossRef]

65. Stevens, V.M.; Trochet, A.; Blanchet, S.; Moulherat, S.; Clobert, J.; Baguette, M. Dispersal syndromes and the use of life-histories to predict dispersal. Evol. Appl. 2013, 6, 630-642. [CrossRef] [PubMed]

66. Thomson, F.J.; Moles, A.T.; Auld, T.D.; Kingsford, R. Seed dispersal distance is more strongly correlated with plant height than with seed mass. J. Ecol. 2011, 99, 1299-1307. [CrossRef]

67. Melo, G.C.; Pinheiro, L.T.; Passos, D.C.; Galdino, C.A.B. Spatial organisation of the neotropical lizard tropidurus hispidus (Squamata: Tropiduridae). Salamandra 2017, 53, 435-438.

68. Macdonald, D.W. Dwindling resources and the social behaviour of Capybaras, (Hydrochoerus hydrochaeris) (Mammalia). J. Zool. 1981, 194, 371-391. [CrossRef]

69. Arispe, R.; Venegas, C.; Rumiz, D. Abundancia y patrones de actividad del mapache (Procyon cancrivorus) en un bosque chiquitano de Bolivia. Mastozool. Neotrop. 2008, 15, 323-333.

70. Michalski, F.; Peres, C.A. Anthropogenic determinants of primate and carnivore local extinctions in a fragmented forest landscape of southern Amazonia. Biol. Conserv. 2005, 124, 383-396. [CrossRef]

71. Bou, N.; Cuyckens, G.; González, E.; Meneghel, M. Conservation planning in Uruguay based on small felids (Leopardus spp.) as umbrella species. Stud. Neotrop. Fauna Environ. 2019, 54, 169-180. [CrossRef]

72. Giordano, A.J. Ecology and status of the jaguarundi P uma yagouaroundi: A synthesis of existing knowledge. Mammal Rev. 2016, 46, 30-43. [CrossRef]

73. Clauzel, C.; Foltête, J.; Girardet, X.; Vuidel, G. Graphab 2.4. User Manual. 2019. Available online: https:// sourcesup.renater.fr/ www / graphab / download/manual-2.4-en.pdf (accessed on 9 June 2020). 
74. Saura, S.; Estreguil, C.; Mouton, C.; Rodríguez-Freire, M. Network analysis to assess landscape connectivity trends: Application to European forests (1990-2000). Ecol. Indic. 2011, 11, 407-416. [CrossRef]

75. Arnan, X.; Arcoverde, G.B.; Pie, M.R.; Ribeiro-Neto, J.D.; Leal, I.R. Increased anthropogenic disturbance and aridity reduce phylogenetic and functional diversity of ant communities in Caatinga dry forest. Sci. Total Environ. 2018, 631-632, 429-438. [CrossRef]

76. Halinski, R.; Garibaldi, L.A.; Dos Santos, C.F.; Acosta, A.L.; Guidi, D.D.; Blochtein, B. Forest fragments and natural vegetation patches within crop fields contribute to higher oilseed rape yields in Brazil. Agric. Syst. 2020, 180, 102768. [CrossRef]

77. Bodin, Ö.; Saura, S. Ranking individual habitat patches as connectivity providers: Integrating network analysis and patch removal experiments. Ecol. Model. 2010, 221, 2393-2405. [CrossRef]

78. Huang, I.B.; Keisler, J.; Linkov, I. Multi-criteria decision analysis in environmental sciences: Ten years of applications and trends. Sci. Total Environ. 2011, 409, 3578-3594. [CrossRef]

79. Talukdar, S.; Singha, P.; Mahato, S.; Shahfahad; Pal, S.; Liou, Y.-A.; Rahman, A. Land-Use Land-Cover Classification by Machine Learning Classifiers for Satellite Observations-A Review. Remote. Sens. 2020, 12, 1135. [CrossRef]

80. Beuchle, R.; Grecchi, R.C.; Shimabukuro, Y.E.; Seliger, R.; Eva, H.D.; Sano, E.; Achard, F. Land cover changes in the Brazilian Cerrado and Caatinga biomes from 1990 to 2010 based on a systematic remote sensing sampling approach. Appl. Geogr. 2015, 58, 116-127. [CrossRef]

81. Cunha, A.P.M.A.; Alvalá, R.C.S.; Kubota, P.Y.; Vieira, R.M.S.P. Impacts of land use and land cover changes on the climate over Northeast Brazil. Atmos. Sci. Lett. 2015, 16, 219-227. [CrossRef]

82. Fernandes, M.R.D.M.; Matricardi, E.; De Almeida, A.Q.; Fernandes, M.M. Mudanças do Uso e de Cobertura da Terra na Região Semiárida de Sergipe. Floresta Ambient. 2015, 22, 472-482. [CrossRef]

83. Hepcan, C.C. Quantifying landscape pattern and connectivity in a Mediterranean coastal settlement: The case of the Urla district, Turkey. Environ. Monit. Assess. 2013, 185, 143-155. [CrossRef]

84. Cayuela, L.; Benayas, J.M.R.; Echeverría, C. Clearance and fragmentation of tropical montane forests in the Highlands of Chiapas, Mexico (1975-2000). For. Ecol. Manag. 2006, 226, 208-218. [CrossRef]

85. Hirayama, H.; Tomita, M.; Hara, K. Quantitative monitoring of changes in forest habitat connectivity following the great eastern Japan earthquake and tsunami. Landsc. Ecol. 2020, 35, 1519-1530. [CrossRef]

86. Pfeifer, M.; Lefebvre, V.; Peres, C.A.; Banks-Leite, C.; Wearn, O.R.; Marsh, C.; Butchart, S.H.M.; Arroyo-Rodríguez, V.; Barlow, J.; Cerezo, A.; et al. Creation of forest edges has a global impact on forest vertebrates. Nature 2017, 551, 187-191. [CrossRef]

87. Ashrafzadeh, M.R.; Khosravi, R.; Adibi, M.A.; Taktehrani, A.; Wan, H.Y.; Cushman, S.A. A multi-scale, multi-species approach for assessing effectiveness of habitat and connectivity conservation for endangered felids. Biol. Conserv. 2020, 245, 108523. [CrossRef]

88. Mendenhall, C.D.; Karp, D.S.; Meyer, C.F.J.; Hadly, E.A.; Daily, G.C. Predicting biodiversity change and averting collapse in agricultural landscapes. Nature 2014, 509, 213-217. [CrossRef]

89. Lyra-Jorge, M.C.; Ciocheti, G.; Pivello, V.R. Carnivore mammals in a fragmented landscape in northeast of São Paulo State, Brazil. Biodivers. Conserv. 2008, 17, 1573-1580. [CrossRef]

90. Akçakaya, H.R.; Mills, G.; Doncaster, C.P. The role of metapopulation conservation. In Key Topics in Conservation Biology; Macdonald, D.W., Service, K., Eds.; Blackwell Publishing: Oxford, UK, 2007; pp. 64-84.

91. Laurance, W.F. Do edge effects occur over large spatial scales? Trends Ecol. Evol. 2000, 15, 134-135. [CrossRef]

92. Brasil Congresso Nacional do Brasil. Protecão da Vegetacão Nativa (Ley N ${ }^{\circ}$ 12651). Available online: https://www2.camara.leg. br/legin/fed/lei/2012/lei-12651-25-maio-2012-613076-veto-136200-pl.html (accessed on 25 March 2021).

93. Zabel, F.; Delzeit, R.; Schneider, J.M.; Seppelt, R.; Mauser, W.; Václavík, T. Global impacts of future cropland expansion and intensification on agricultural markets and biodiversity. Nat. Commun. 2019, 10, 1-10. [CrossRef] [PubMed]

94. Schulz, K.; Guschal, M.; Kowarik, I.; De Almeida-Cortez, J.S.; Sampaio, E.V.D.S.B.; Cierjacks, A. Grazing reduces plant species diversity of Caatinga dry forests in northeastern Brazil. Appl. Veg. Sci. 2019, 22, 348-359. [CrossRef]

95. Wittman, H.; Chappell, M.J.; Abson, D.J.; Kerr, R.B.; Blesh, J.; Hanspach, J.; Perfecto, I.; Fischer, J. A social-ecological perspective on harmonizing food security and biodiversity conservation. Reg. Environ. Chang. 2017, 17, 1291-1301. [CrossRef]

96. Bucher, E.H. Chaco and Caatinga-South American Arid Savannas, Woodlands and Thickets BT-Ecology of Tropical Savannas; Huntley, B.J., Walker, B.H., Eds.; Springer: Berlin/Heidelberg, Germany, 1982; pp. 48-79.

97. Maneta, M.; Torres, M.; Wallender, W.; Vosti, S.; Kirby, M.; Bassoi, L.; Rodrigues, L. Water demand and flows in the São Francisco River Basin (Brazil) with increased irrigation. Agric. Water Manag. 2009, 96, 1191-1200. [CrossRef]

98. Tamburini, G.; Bommarco, R.; Wanger, T.C.; Kremen, C.; Van Der Heijden, M.G.A.; Liebman, M.; Hallin, S. Agricultural diversification promotes multiple ecosystem services without compromising yield. Sci. Adv. 2020, 6, eaba1715. [CrossRef] [PubMed]

99. De Araujo, H.F.; Machado, C.C.; Pareyn, F.G.; Nascimento, N.F.D.; Araújo, L.D.A.; Borges, L.A.D.A.; Santos, B.A.; Beirigo, R.M.; Vasconcellos, A.; Dias, B.D.O.; et al. A sustainable agricultural landscape model for tropical drylands. Land Use Policy 2021, 100, 104913. [CrossRef]

100. Schulz, C.; Koch, R.; Cierjacks, A.; Kleinschmit, B. Land change and loss of landscape diversity at the Caatinga phytogeographical domain-Analysis of pattern-process relationships with MODIS land cover products (2001-2012). J. Arid Environ. 2017, 136, 54-74. [CrossRef] 